\title{
LEGAL PLANNING FOR AGRICULTURE
}

\section{FARNSWORTH L. JENNINGS AND ROBERT C. SULLIVAN†}

A decision which to a critic of the legal system is sure to seem a labored attempt to maintain our competitive regime is that of New State Ice Company v. Liebmann. ${ }^{1}$ To the more lawyerly minded the case will perhaps create not so much dissent as provocation. Not less interesting than the decision are some of the sweeping dicta with which the majority opinion is generously provided. One statement of the court is as follows: "And this court has definitely said that the production or sale of food or clothing cannot be subjected to legislative regulation on the basis of a public use; . . ." 2

This utterance represents the crystallization of a judicial attitude which has halted or rendered inadequate all attempts at exorcising the twin demons of low prices and over-production that have possessed portions of the farming industry in recent years. ${ }^{3}$ Such utterances make it possible for the industry to shift a share of the blame upon the law.

Mr. Justice Brandeis in his dissenting opinion in the New State Ice Company case, said:

"The people of the United States are now confronted with an emergency more serious than war. Misery is widespread, in a time, not of scarcity, but of overabundance. The long-continued depression has brought unprecedented unemployment, a catastrophic fall in commodity prices, and a volume of economic losses which threaten our financial institutions. . .

$\dagger$ Farnsworth L. Jennings is a Sterling Fellow and Robert C. Sullivan is a Research Assistant in the Yale School of Law. The authors gratofully acknowledge their indebtedness to Professor Walton H. Hamilton.

1. 285 U. S. 262 (1932).

2. Id. at 277 .

3. No case involving the constitutionality of a statute restricting the production of food or clothing has been decided by the courts. The icu case presents the closest parallel. Compare also F. Bourland Ice Co. v. Franklin Utilities Co., 180 Ark. 770, 22 S. W. (2d) 993 (1929). The Supremo Court of Wisconsin has declared that a statute of that state which forbado the manufacture of oleomargarine violated the constitution of Wisconsin. Contrast Champlin Refining Co. v. Corporation Commission, 286 U. S. 210 (1932), upholding a state statute designed to conserve the oil and natural gas supply of a state. For a discussion of this problem, see Marshall and Moyors, Logul Planning of Petroleum Production: Two Years of Proration (1933) 42 YALE L. J. 702. For other dicta asserting that such regulation would bo unconstitutional see Ribnik v. MeBride, 277 U. S. 350 (1928); Tyson \& Brothor V. Banton, 273 U. S. 418 (1927); Charles Wolff Packing Co. v. Court of Industrial Relations, 262 U. S. 522 (1923). 
Economists are searching for the cause of the disorder and are reexamining the basis of our industrial structure. Business men are seeling possible remedies. Most of them realize that failure to distribute widely the profits of industry has been a prime cause of our present plight. But rightly or wrongly, many persons think that one of the major contributing causes has been unbridled competition... men point to the excess capacity of our productive facilities resulting. from their vast expansion without corresponding increase in the consumptive capacity of the people ... All agree that irregularity in employment-the greatest of our evils-cannot be overcome unless production and consumption are more nearly balanced. Many insist that there must be some form of economic control." 4

Over these fundamental shifts in economic relationships to which Mr. Justice Brandeis refers a notable fog persists. The merest outline of the subject becomes so intricate that it is not easy to see it steadily and as a whole. Explanation, argument and recrimination have done little to bring consensus of opinion. However, the incidence of our present economic crisis, which has not become much less mysterious as it has become more prolonged, has not fundamentally affected the agricultural situation. For the farmer the depression did not begin in 1930.5 It began with the economic maladjustments of productive capacity created by war conditions and maintained by the growing inelasticity of the present economic structure. Consequently, the case of agriculture may be said perhaps to be somewhat clearer than is the general industrial picture. ${ }^{0}$

\section{The Economy of Farming}

The fact that farming has been in a very unhealthy condition for over a decade even the least critical must admit. It has not only

4. Supra note 1, at 306 et seq.

5. See 1 RECENT SocLAL TRENDS (1933) 223: "This high prosperity of the United States in the post-war years was, however, not shared by agriculture. Some time before the present depression the state of American agriculture had began to illustrate the instabilities of the world economy through the decline in agricultural prices, the decrease in the value of farm property and the persistence of a large burden of farm debt incurred when both the prices of farm property and of agricultural products were at much higher levels. It is indeed not unlikely that the standard of living of the American farmer in the post-war era was in part sustained by the proceeds of mortgage debt which he found . it increasingly difficult to liquidate. The existence of this condition of agricultural depression was confirmed by the steady and increasing number of banls failures in the rural areas which long antedated the wave of suspension of city banks occasioned by the business depression of 1930." See also ANNoar REPORT OF SECRETARY OF AGRICULTURE (1931) 24.

6. For conditions in other fields which in material respects closely parallel those of agriculture, see HAMIITTON AND WRIGHT, THE CASE OF BITUMINods CoAL (1925) and Mrarshall and Mreyers, Legal Planning of Petroleum Production (1932) 41 YaIe L. J. 33. 
long since ceased to be a paying business but it has become a losing one. ${ }^{7}$ It has been carried on by making heavy demands on the people who are engaged in it and at the sacrifice of soil-conservation and capital assets. Allowance for interest on investments or for depreciation no longer have a place in the accounting of the farmer. ${ }^{8}$

7. The receipts of $29 \%$ of the farmers, according to the YaArBook or AGRICULTURE (1932) 895, were substantially less than their cash outlay for production purposes in 1930 . In the same year $59 \%$ of the farmers received net returns of less than $\$ 500$, and $17 \%$ received more than $\$ 500$ but less than, $\$ 1,000$.

The Department of Agriculture estimates that the cost of producing with reasonable efficiency a bushel of wheat is $\$ 1.09$. On March 1, 1933, wheat was selling in primary markets at $\$ .63$ a bushel. The cost of producing a bushol of corn is estimated at $\$ .89$. On March 1st the selling price in primary markots was $\$ .39$. Cotton which costs $\$ .20$ a pound to produce was selling at $\$ .06$ a pound. These selling prices are even higher than the record low made during the summer of 1932 .

The index number for all grain prices (pre-war average 1910-1914 being taken as 100) in December, 1931, was 52 . Cotton stood at 45; fruits and vegotables at 68 ; meat animals at 68 ; dairy products at 92 ; and poultry products at 120. However, the average for the year for poultry products stood at 94 .

In December, 1932, prices of all farm products stood at an index of 54, prices paid by farmers for commodities bought was 106, farm taxes stood at about 250, farm wages 84 . The general wholesale price level of all commodities atood at 94. Industrial wage rates were around $\mathbf{1 7 5}$.

8. The gross income from farm production was twelve billion dollars in 1929, which was considered a lean year. It then dropped to something over nine billions in 1930, to seven billions in 1931, and will run around five billions for 1932. See The Agricultural Situation, Department of Agriculturu Bullenis (December 1, 1932) p. 2.

Statistics compiled at the University of Illinois from account books of about one thousand farms show earnings of $1.8 \%$ on the farm investment in 1927 as compared with $4.3 \%$ in $1924,3.3 \%$ in 1925 , and $2.3 \%$ in 1926 . This roturn has practically disappeared in the last three years. JOHN D. BLAOK, AGRrour TURAL REFORM IN UNITED STATES (1929) 21.

Current Value of Capital Employed in Agriculture and Income Avatlable for Capitar and Management, 1924-1930.

\begin{tabular}{|c|c|c|c|c|}
\hline \multirow[t]{2}{*}{ Year } & \multicolumn{2}{|c|}{ Total Capital ${ }_{\text {Total Used }}$} & \multirow{2}{*}{$\begin{array}{c}\text { Income available } \\
\text { for capital } \\
\text { and management }\end{array}$} & \multirow{2}{*}{$\begin{array}{c}\begin{array}{c}\text { Incomo as } \\
\text { per cont } \\
\text { of capital }\end{array} \\
\text { Per cont }\end{array}$} \\
\hline & - Million Dollars & Million Dollars & & \\
\hline 1924 & 57,718 & 51,293 & 1,088 & 4.0 \\
\hline 1925 & 57,861 & 51,304 & 1,292 & 4.7 \\
\hline 1926 & 56,754 & 50,065 & 1,005 & 3.7 \\
\hline 1927 & 57,256 & 50,436 & 1,065 & 3.9 \\
\hline 1928 & 58,141 & 51,189 & 972 & 3.4 \\
\hline 1929 & 58,130 & 51,046 & 1,060 & 3.8 \\
\hline 1930 & 52,747 & 45,747 & -346 & -1.4 \\
\hline
\end{tabular}


Indeed the returns from farming have been so meagre in the postwar period that the outlay has been met only by consistently adding to the structure of a vast indebtedness ${ }^{\circ}$ which has finally resulted in the situation that is now being dramatized by the activities of farmer organizations.

That concern for the farmer is not merely a matter of altruism, appropriate as that is, is abundantly demonstrated on every side. The general public has only a less concern in the restoring of prosperity to the farming districts than have the farmers themselves. There are two facets to the industry of agriculture. One is to provide its products at not more than a reasonable cost. The other is to secure to farmers a standard of living approaching that of other industrial groups. Neither of these can be precisely defined. Conflicts in economic society do not admit of final determination. At the same time the integration of our economic society is now so complete that in the larger view conflicts between industrial groups have lost the sharpness they once possessed. The derangement of farming has resulted in the gradual diminishing of the farmers' purchasing power, ${ }^{10}$ to the hurt of manufacturers and their employees. Until the purchasing power of the farmer is restored, the recovery of industry will be seriously retarded. ${ }^{11}$ Even more important, possibly, has been the imperilling of the general financial structure. Liquidation of farm assets has become so difficult and disorganized that a great deal of capital has been frozen. Farm obligations have been successfully evaded on a wholesale scale, and fear for the future has been intensified. Banks, investment houses, and insurance companies record farm paper as dubious assets while the reverberations of their depreciation have involved the financial integrity of the nation's credit facilities.

[Statement prepared for Interstate Commerce Commission, IIay, 1932. U. S. Departmient OF Agriculture p. 32]:

Agriculture as a whole earned no net income in 1930 and experienced an even greater loss in 1931 and 1932. The sudden and considerable decline in gross income was accompanied by only a moderate decrease in expenses of production, farmers being unable to make any noticeable changes in expenditures except for feed, farm labor and machinery.

9. See note 21, infra.

10. Shrinkage in farm incomes is restricting the purchase of industrial goods. As most of the returns were needed to meet production costs and fixed debt charges and taxes, there has been a drastic curtailment of expenditures. Purchases have been practically limited to bare necessities.

The ratio of prices received to prices paid by farmers gave an index number of 101 in 1914, 118 in 1917, 99 in 1920, 88 in 1923, 85 in 1927, 80 in 1930, and 51 in November, 1932. The Agriculturax Situation, supra note 8, at 21.

11. See EdwIN R. A. SELIGMaN, Economics of FARM LIFE. (1929) Introduction, p. XIII. 
Many interlocking causes, social, economic, and legal have brought farming to its present demoralized state. In the older America of before the war the farmers occupied a relatively favored position.12 The volume of farm products was expanding at a rate slightly below that of a population which was growing rapidly due to a high birth rate and to immigration of over a million a year, ${ }^{13}$ while manufacturing was expanding many times as fast under conditions of rigorous competition. ${ }^{14}$ Industrial integration had only just begun to convert the farm from an independent communal unit into a dependent part of a vast interlocking commercial machine where the money crop of cotton or wheat or tobacco or hogs must

12. In 1820 the percentage of all gainfully employed persons in the United States 10 years or older engaged in agricultural pursuits was 83 por cent. In 1840 the percentage was $77 ; 1870,47 ; 1900,35 ; 1910,33 ; 1920,26$; and in 1930,21 .

Index Numbers of Price levels.

$(1910-1914=100)$

\begin{tabular}{cccc}
\hline & $\begin{array}{c}\text { Prices Received } \\
\text { by Farmers }\end{array}$ & $\begin{array}{c}\text { Prices Paid } \\
\text { by Farmers }\end{array}$ & $\begin{array}{c}\text { Buying Powwor of } \\
\text { Farm Products }\end{array}$ \\
\hline 1910 & 103 & 98 & 106 \\
1920 & 205 & 206 & 99 \\
1925 & 147 & 159 & 92 \\
1928 & 139 & 156 & 90 \\
1930 & 117 & 146 & 80 \\
1932 & 54 & 106 & 51 \\
\hline
\end{tabular}

See the article by Eric England, Ass't Chief Economist, Dopartmont of Agriculture, in the New York Times, February 5, 1933.

13. Ten years ago the population of the nation was increasing noarly $2,000,000$ a year; now the increase is only about 800,000 . The number of children born in the nation is decreasing between 50,000 and 125,000 each year. In the thirty years 1870-1900 the population of the United States was doubled. In the thirty years $1900-1930$ it increased less than 60 per cont. The rate of increase in production of agricultural products closely paralleled the growth in population up to the War period. However, since that time the world population has increased only $10 \%$, whereas world production of food products has increased 16\%. ANNUAL REPORT OF SECRETARY OF AGRiculture (1931) 43, and H. Bading, Changes in Agricultural Technique and Its CONSEQUENCES (1932) 172.

14. In the 30 years between 1899 and 1929 the industrial production had far outstripped population growth; whereas the latter had increased about $60 \%$, industrial output had increased about $200 \%$, or more than threo times the rate of population growth. That industrial expansion of 30 years has been wiped out during the course of the current depression, in progress since 1929, for the ratio of output to population in 1932 was back to that of 1900. The Agricultural OUtlook fOR 1933, U. S. Department of AariCULTURE (Miscellaneous Publication No. 156) 87. 
provide the farmer's living. The farmer was not yet a specialized producer who sold practically the whole of his produce.

The outbreak of the war brought with it the opportunity of feeding the warring nations. Agricultural production and specialization were pushed by this unnatural stimulant to undreamed-of heights. ${ }^{15}$ Land values and prices tripled and quadrupled, ${ }^{10}$ profits were devoted to the purchase of improved machinery and to the bringing in of new land. Millions of new acres were made tillable, and those which were already under cultivation were utilized as effectively as possible. Consequently the reaction which followed the war was immediate and severe. But besides the re-establishment of European farming there was also the fact that even the pre-war purchasing power of both sides had been broken. The feverish event of the war was responsible, furthermore, for the creation of tremendous new producing areas in Canada, Argentine, Australia and South Africa. ${ }^{17}$ However, even after several years had elapsed the condi-

15. During the War the production of wheat was pushed to the unprecedented total of above one billion bushels for one year. The average yield per acre at this time was 17 bushels. In 1910 and in 1911 total production of wheat averaged slightly over 600 million bushels. The average yield per acre was 13 bushels. This represented an increase in output of almost $40 \%$.

16. Index Numbers of Estimated Value of Farmi Real Estate per acre $(1912-1914=100)$

\begin{tabular}{cccccccccccc}
\hline 1913 & 1915 & 1917 & 1919 & 1920 & 1921 & 1922 & 1924 & 1927 & 1930 & 1931 & 1932 \\
100 & 103 & 117 & 140 & 170 & 157 & 139 & 130 & 119 & 115 & 106 & 89 \\
\hline
\end{tabular}

During the pre-war years, 1910-1914, the producers of wheat received $\$ .88$ per bushel. This sum rose to $\$ 2.14$ during the $W a r$, but it had fallen to $\$ .32$ by November, 1932. A similar rise and fall is indicated by cotton, corn, and hog prices:

Cotton

1910-1914 \$.12 per pound

$1917-1918-.27$ " "

$1932-.06$ " *

YEARBOOK OF AGRICULTURE (1932)

Situation, -supra note 8 , at 2.

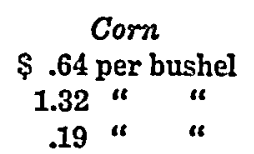

$578,608,658$, and THE

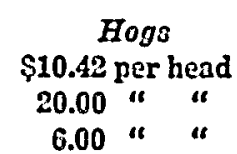

Agnicuztural.

17. In addition, the transformation of the United States, as a result of the war, from a foremost debtor to an outstanding creditor nation has made the foreign disposition of agricultural surpluses increasingly difficult. During the twelve years since the war we normally have been exporting more than one-half of our cotton, one-fourth of our wheat and nearly one-half of our packing house lard. "Since 1919 the problem of the United States has been to learn how to act as a creditor nation. Unfortunately, it is a terrific job to change suddenly the psychology of a pioneer debtor people to that of a mature creditor nation. For twelve years we have been stumbling in the dark, refusing to make the plans which a creditor nation must make if it is 
tion of agriculture did not begin to improve. It became increasingly evident that new factors had come into being which quite apart from the war spelled agricultural distress. Productive capacity, far from undergoing any readjustment, actually continued to grow, while demand began relatively to decrease. The ominous deduction was inevitable that agricultural production was breaking away from the requirements of population. According to a statement of tho present Secretary of Agriculture, "there are some 50,000,000 acres of crop land in the United States producing food, cotton and tobacco which cannot be consumed inside the country." 18 This is a far cry from the "scarcity economics" preached during the nineteenth century. when there was genuine concern over the feat of getting a sufficient supply of agricultural products. The trick which the acute mind of Malthus believed impossible has been done with an added gesture. ${ }^{19}$

to avoid disaster." Henry A. Wallace, Secretary of Agriculture, in the Now York Times, January 22, 1933.

18. In the New York Times, January 22, 1933. See also ANNUAL Rapont of the SECretary of AGRiculture (1931) 24: "Barring such temporary fall in demand as we experienced in the past year due to world-wide business dopression, our difficulty is not a sudden emergency, but a cumulative overproduction."

19. In 1927, W. J. Spillman, Agricultural Economist for the Bureau of Agricultural Economics, Department of Agriculture, estimated that the surplus acreage under cultivation (that is, in excess of normal requirements) as to each of our five major crops was as follows: wheat, 8 million acres; cotton, 10 million acres; corn, 6 million acres; oats, 6 million acres; hay, 8 million acres.

The indices of the volume of net agricultural production in the United States $(1919-1927=100)$ are as follows: 1921,$87 ; 1923,101 ; 1925,106 ; 1927,106$; 1929, 109; 1931, 111. Statement prepared for. Interstate Commerco Commission, supra note 8 , at 11 .

While world population during the past five years has been about $18 \%$ greater than in 1913, world production of leading crops has averaged $23 \%$ greater. Wheat has increased $40 \%$ in world production since 1000 . The world's wheat area is 42 million acres larger than it was before tho war. These figures do not include Russia's acreage which has doubled in the past six years. Wheat surpluses have piled up steadily. On August 1, 1930, tho world carry-over exceeded 500 million bushels.

The area sown to wheat in our southwestern winter wheat states increased approximately 4 million acres from 1924 to 1929. During the same period tho area in Canada, Argentina, and Australia combined, increased more than 10 million acres. This is in line with the trend in expansion since 1910. In the last seven years the world has produced an annual average of 43 million bushels of wheat more than has been consumed, and the United States carryover has piled up to the record total of 275 million bushels. THE Agricuiturax OUTLOOK FOR 1933, 15. Even for the 1932-33 season the total whent area of the world has been increased by 4,500,000 acres. In the United States a supply 
The recovery of industry from the aftermath of the war came with astonishing rapidity. It was made possible principally through the medium of a vastly growing consumption of its output. The development of automobile production and distribution, of airplanes, radios, motion pictures and a hundred other products of the new machine age took up the pressure of maladjustment. But the farmer has encountered no such good fortune. The capacity of the human stomach is limited and even the wardrobe is among the more finite of human requirements. Along with the restriction on immigration

of about 1,015 million bushels, or around $350,000,000$ to $375,000,000$ bushels in excess of probable domestic utilization for the season is predicted.

The world supply of American cotton for 1932-33 is now estimated to be only slightly less than the record supply of $1931-32$ and is more than twice the world consumption of American cotton during 1931-32. Reports on foreign production received up to mid-January, 1933, indicate that in 1932-33 it will be about 900,000 bales larger than in 1931-32. The apparent supply of American cotton in the United States on January 1, 1933 was 15,800,000 bales. The carryover constitutes the largest part of the total supply. At 13 million bales it is $4,100,000$ bales larger than world consumption in 1931-32. Consumption of all cotton in the United States was 4,900,000 bales in 1931-32 as compared with $5,300,000$ bales in 1930-31. United States Departarent of Agriculture (ariscellaneous Publication No. 139, 1932).

A study of the market records of the principle crops of the country brings out very forcefully the fact that the farmer very seldom, if ever, gets as large a return for any crop that is overproduced as he does for one of the size normally absorbed by the market. On cotton in 1924, the production of a little more than $13,500,000$ bales sold for approximately 23 cents a pound; two years later a production of $18,000,000$ bales sold for about 12 s. cents a pound; the following year's production of $13,000,000$ bales sold for slightly over 20 cents a pound, indicating that as production increases sharply above the normal consuming demand, the price declines rapidly and increases just as quickly when the production drops below the consumption requirements.

On surplus capacity in agricultural production, see: Inving Fisher, Boosss AND DEPRESSIONS (1932) 171; STAMFORD UNIVERSITY FoOd RESEARCH INSTITUTD (Miscellaneous Publication No. 6, 1932) 658; O. Fred Boucke, LaISSEZ FAIRE AND AFTER (1932) c. $X$ and note on farmers, 241 et scq.; Scoville Hamlin, ed., THE MiENace of Overproduction (1930) 51; WALLACEs Fararer (April 16, 1932) "Can We Control Production?" 219-220; StUart Chase, OUT OF THE Depression AND AFTer (1931) Part II, "Master Planning"; Gronge SouLe, A PlanNen Sochety (1932) c. IX, X; Bernard M. Baruch, A Plan for the Regulation of Production in A PHILOSOPHY of Production (George Fredericl, ed., 1932); WILSON GFe, The SOCLAL ECONOMICS OF Agriculture (1932) 77; OnvmLE MT. KIE, THE NEW Agriculture (1932); Arthur M. Hyde, Agricultural Teeter Board (October, 1931) REview of REviews; E. G. Nourse, Can the Amorican Farm be Saved? in A Practical Program for Aaierica (Henry Hazlitt, ed., 1932); Migad aNd Ostrolenk, Harvey BaUd, A Study of the Agriculturat Revolution (1928); W. J. Spillaian, Balancing the OUTPUt (1927); Charence A. WILeY, Agriculture AND the Business Cycle since 1920 (1930); U. S. Departient of Agriculture (Technical Bulletin No. 297, 1932) 38. 
has gone a steadily declining birth rate, so that increase in demand for farm produce has become very nearly negligible. On the other hand an immense and a potentially still more consequential source of excess supply has resulted from the vigorous efforts of the agricultural sciences-the expanding mechanization of the farms, the practice of scientific cultivation, and a shift to more productive crops. $^{20}$ Technology, gathering momentum since the lusty shove given it by the World War, bids fair to complete a transformation of agriculture not less far-reaching in its consequences than has occurred in industry. But even with present methods, it may be estimated that probably one-third of the human and natural resources employed in agriculture are unnecessary. What will be the figure in the very near future only a sayer of revelations could tell us. If order is to be brought into farming this vast source of excess supply must not be allowed to continue without direction. Along with this onward march of technology has gone the opening up of considerable amounts of new land, particularly in Texas, Oklahoma, California and Montana. Even the disappearance of the horse has joined in the conspiracy to help agricultural production outrun demand by setting free for other crops nearly fifteen million acres of land previously employed in raising oats and hay.

The simplest possible catalogue of the ills of farming cannot, however, be restricted to the associated matters of overproduction, surpluses and low prices. In fact it is another situation which has

. 20. Professor J. D. Black estimates (Agricultural REForM IN THE UNITED STATES (1929) 13) that "production per farm has increased nearly 30 por cont since 1910." The revolution in farm machinery which accompanied tho Civil W.ar was mainly confined to harvesting machinery. Beyond this, thore was little improvement in agricultural practice. Aside from a fow machines, farming was carried on as it was in, the middle ages. By 1890, the total value of all farm implements in the United States was still less than one-half billion dollars. It had risen to $\$ 750,000,000$ by 1900 , and by 1910 , it had mounted to one and one-quarter billion dollars, a slow rate of growth corresponding to the increase in acreage. By 1920, however, the value of farm implements had more than doubled, reaching a figure of more than three and one-half billion. U. S. DEPARTMENT OF Commerce (Statistical Abstract, 1925) pp. 584, 602.

. The Special Committee of the Association of Land-Grant Colleges and Universities reported in Novenber, 1932, that the total farm output had increased 15 per cent since the war despite the fact that the number of farms declined during this period about 2 per cent, and the number of people gainfully omployed in agriculture declined about 4 per cent. The report estimates an increaso of about 20 per cent in production per person employed, brought about by increased mechanization, improvements in animal and field husbandry, and šhifts from less productive to more productive crops and animals. See H. W. Quaintance, The Influgnce of Farm Machinery Ufon Production AND LABOR, (Publications of the American Economic Association, 3rd ser., vol. V, no. 4,1904 ) 39. MEAD AND OSTROLENK, op. cit. supra note 19, at 21. 
suddenly become most heavily charged with issues and emotionsthe immense debt structure, under which farming struggles and which, during this period of deflation and acute agricultural distress, embraces the fair value of a substantial portion of the farms." It

21. See Farm Mortgage Credir Department of Agriculture (Technical Bulletin No. 288, 1932) by David L. Wickens, Agricultural Economist, Division of Agricultural Finance.

Total Farm Mortgage Debt of the Nation

Millions

\begin{tabular}{|c|c|c|}
\hline 1910 & & $\$ 3$ \\
\hline 1920 & & 7,8 \\
\hline 1925 & & 9, \\
\hline 1928 & 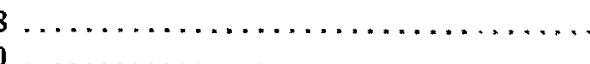 & 9,4 \\
\hline
\end{tabular}

The fixed annual charge on this debt in 1930 approximated $\$ 568,000,000$. Since 1930 the total debt has declined to about $\$ 8,500,000$ according to approximations based in part on the fact that the total outstanding farm mortgage loans by principal lenders-the Federal and the joint stock land banks and 40 important life insurance companies-declined about $8 \%$ from the beginning of 1930 to September, 1932. The greater share of the debt reduction no doubt was due to foreclosures.

Distressing as the situation is at present, it should be noted that $58 \%$ of all farms in the United States are free of mortgage debt. The proportion of each of four leading crops grown on mortgaged land in the U. S. is estimated by Mr. Wickens as follows: Corn-46.6 per cent; Wheat-50.1 per cent; Cotton -42.8 per cent; Tobacco-31.7 per cent. Total, 4 crops-45.3 per cent. Proportion for 75 crops- -45.5 per cent.

The bulk of the present farm mortgage debt was incurred in years when the general price level was about twice, and the level of farm prices nearly four times as high as at the close of 1932 . The creditor in most cases, therefore, lent about one-half the purchasing power now owed him.

Eric Englund, Assistant Chief of the U. S. Bureau of Agricultural Economics, estimates that the relationship of debt to value of land and buildings in mortgaged farms was $47 \%$ in 1932. About $36 \%$ of mortgaged farms are mortgaged for more than $50 \%$ of their present value, about $16 \%$ for more than $75 \%$ of their sale value, and about $5 \%$ for more than $100 \%$ of their sale value. The farms mortgaged for more than half of what they would now bring on the market, number about 800,000 or slightly over $13{ }^{\prime} c$ of the $6,000,000$ farms in the U. S. It is in this group that most of the difficulty in meeting mortgage payments has been experienced.

In addition to the mortgage debts, short-term loans to farmers from banlis approximate $\$ 2,000,000,000$. Merchant credit, loans by individuals, and other forms of indebtedness amount to more than $\$ 1,000,000,000$.

Reports of changes in farm ownership between March, 1930, and MIarch, 1931, indicate that $42 \%$ of all the transfers of farms were forced sales as compared with $34 \%$ in each in the two preceding years. Data for 1931-32 are not yet available, but it is certain that the proportion of transfers that are forced sales has been increasing steadily. Statements from the agricultural colleges of nearly every state point out the seriousness of the farm debt situation. See Report of the Special Commitree of the Associatron of LAND-Grant Colleges aNd UNIVERSITIES (November, 1932) 21. 
is this situation which has been brought before the eyes of the nation by the foreclosure moratoria, the general insecurity of the financial institutions concerned with farm credit, and the "holiday boys" of the corn belt who have resorted to a miniature revolution to retain their homes. During the past few years net returns have been insufficient to pay the charges of mortgages. Foreclosures to the amount of a billion dollars have occurred since 1929 and many thousand farmers have been dispossessed or made tenants. Practically all mortgage loan agencies are now involved in salvaging and liquidation. However, to a considerable extent farm foreclosures have become inexpedient and a policy of forbearance has become necessary. With the exception of the Federal Land Banks and a limited number of banking agencies, all the sources of farm credit have dried up. As an adventitious aspect of the farm situation, the problem of debt, foreclosure and credit has been translated into the most relevant eventuality with which the farmer and the credit institutions of the country are faced.

Although in its dramatic consequences this problem of debts is peculiar to the day, fundamentally it represents only the long-time failure to effect a satisfactory rationalization of production. The three years of crisis have only served to bring into startling relief a farm mortgage situation that had been growing steadily into threatening proportions ever since the war when the farmers essayed the role of financier which initially bargained them into what has turned out to be a permanent state of debt. However, not only has the meagre income of farming been insufficient to amortize the debts undertaken in this period of feverish expansion and high prices, but for the last decade farming as a losing business has been forced to resort more and more to mortgaging its capital assets in order to meet its everyday expenses of operation. On the diminishing volume of income and wealth this expanding burden of debt has increasingly pressed.

On the other hand, however, the problem of the debt structure cannot be put to one side in the hope that by again placing farming

All in all, it appears certain that gross cash in the past two years has fallen to a level so low that nearly all of it would be required to pay mortgago charges and taxes on farms mortgaged at more than three-fourths of full value. One thousand bushels of corn, which would have paid off $\$ 1,436$ of mortgage or interest in 1920, paid off only $\$ 120$ in 1932 . A thousand bushels of wheat had fallen from $\$ 2,443$ to $\$ 330$. A thousand pounds of hogs, worth $\$ 133.60$ in 1920 now bring but $\$ 29$. Instead of $\$ 89.90$, a thousand pounds of beef cattle now mean $\$ 39$ or less. If an expert had selected tho worst possible time for many of these mortgages to fall due he could hardly havo excelled the last two years. 
on a profitable basis other issues may be left to themselves. The comforting assurance that the debt situation will be gradually ameliorated by balancing output with consumption is hardly enough for immediate need, particularly when there is no convincing evidence that the story can be finished. By the same token, such a program fails to take into account the critical requirements of that other owner of American agriculture whose plight can no more easily be rationalized-the banks, insurance companies, and investment houses. Both parties to the debt tie are equally unsatisfied, and there must be a realistic balancing of interests and pressures. The legal aspects of the matter under the caption of sanctity of contract are involved enough. Prospectively, the forces of economic rehabilitation seem most intimately geared to the conflicting demands of the restoring of creditor-confidence and of the freeing of debtors from obligations so burdensome as to mean virtual peasantry. 22

The only cheerful note that has been sounded in the whole piece is the pious hope that the operation of economic "laws" may be trusted to restore agriculture to a state of balance in the general industrial culture. However, in spite of the theories which have lingered on from nineteenth century economics the period of agricultural distress has dragged on from year to year until there is no longer anything heroic in pointing out that, at least in agriculture, the machinery upon which a competitive order depends for its functioning, simply will not run. For as long as any cautious person would care to estimate, the inability of farm production to accommodate itself to demand seems destined to remain a permanent characteristic.

Economically speaking, agriculture is not an industrial organization but a family craft which at the same time presents problems of fixed investment and high overhead. ${ }^{23}$ The variable costs of production are small; even labor costs do not vary with the yield. The "hands" of the farm are the farmer and his household. If farming is using more of human resources than is necessary, there is little possibility of achieving economy by curtailing personnel. Consequently the individual farmer has no way of reducing outlays to adjust himself to a fall in prices. In fact a fall in prices which makes it difficult for the farmer to make ends meet only causes him to work harder and produce more. The "law" of supply and demand, if it can be

22. On the farm credit situation, see: BLACK, AGricultural REFons IN THE United States (1929), c. XXI; Aterander J. Boyazoglu, Agriculturat Credit (1933), Frieda Batrd, Ten Years of Federal Interdiediate Farat CREDIT (soon to be published).

23. See Wilet, Agriculture and the Business Cycle since 1920 (1930) 62 et seq. 
said to work at all, has more than occasionally a tendency to work in an inverse manner. The paramount question for the farmer is not the costs per unit but the total amount and value of his crop, and any one of the six million farmers has so negligible an influence on the general situation that the maintenance of price and production policies by the individual is out of the question. In industry producers are so large and few that to some extent they can by their own efforts control their commodity. The biggest producers may even expect their smaller competitors to conform to their prices. ${ }^{24}$ Nor is the farm a business enterprise only. It is also a home, and farming a mode of life. Consequently the "submarginal producer" does not easily betake himself to searching out new and strange paths of existence. Hoping against hope he stays on awaiting better times.

Finally, American agriculture has no longer any chance to seek readjustment by turning to foreign markets. ${ }^{25}$ Agricultural depression is general in scope, at least so far as the western hemisphere is concerned. ${ }^{26}$ The phenomena of unruly productive capacity, destructive surpluses, decreasing demand and low prices prevail everywhere. The struggle for foreign markets under existing conditions is a hopeless one. No doubt our farmers may some day caunt on the possibility of selling to China, India, and Japan. However, the course of events offers no immediate hope for American agriculture to include these countries in its planning except at impossibly low prices or at a thoroughly disadvantageous level of exchange.

\section{The Cooperative Movement}

The farmer, traditionally an individualist, has made at best only faint attempts to find an economic and legal basis for bringing his house into order. Generally speaking, his efforts have amounted to only a chapter of stumbling experiment in the cooperative marketing of crops, frantically scribbled in the midst of falling prices. Still this far from perfect machinery is the only instrument at present protecting him from the full shock of economic disorder. The co-

24. Consider the influence which the United States Steel Corporation exorts on the steel industry. See KEgzer and MAY, The Public Controu of Business (1930).

25. High tariff barriers have been raised against products which wo normally export. The tariff on wheat imports in Germany is $\$ 1.62$ per bushol; in France it is $\$ .87$ per bushel. Spain and Italy have barriers equally insurmountable. Our exports of agricultural products have dropped from ubout $30 \%$ of our total farm production to about $10 \%$ of the total.

26. See note 19, supra. 
operative rationalization of production has never commanded his support or sympathy. Indeed, since the cooperative movement cuts athwart the law designed to protect competition, even his efforts at organized marketing would for the most part have been ill-advised had it not been for the tolerance and sympathy of the courts and the ready responsiveness of the legislature. The legal problems involved in the cooperative movement are not simple. It must not constitute a device to control prices or production in contravention of statute and the common law. However, in certain directions the decisions have been able to fortify the scattered efforts of farmers to consolidate their economic strength, ${ }^{27}$ while the state legislatures, in the hope that the cooperative movement may substantially overcome the hardships with which the farmers contend, have gone far beyond. the courts.

It seems clear that cooperative associations are now safe from prosecution as constituting per se restrictions of trade. Here, as in other instances, the path of the courts has been made easy by statutes adopted in most of the states providing that an association organized under the acts ". . . shall be deemed not to be a conspiracy nor a combination in restraint of trade nor an illegal monopoly; nor an attempt to lessen competition or to fix prices arbitrarily or to create a combination or pool, in violation of any law of this State; . . "28 There are also further provisions that the marketing contracts and agreements between the association and its members and any agreements authorized in the act shall not be considered to be illegal or in restraint of trade or contrary to the provisions of any statute enacted against pooling or combinations. The congressional exemptions in the Clayton and Capper-Volstead acts of agricultural cooperative organizations from prosecution under the federal anti-trust laws have not yet been tested in a case before the United States Supreme Court, and it is possible that the exemptions may be whittled away as has happened in the instance of

27. See generally on the legal status of cooperatives: Hamilton, Judicul Tolerance of Farmers' Cooperatives (1929) 38 YALE L. J. 936; Tobriner, Tho Constitutionality of the Cooperative Irarketing Statutes (1928) 17 CaLIF. L. REv. 19; Keegan, Power of Agricultural Coopcrative Associations to Limt Production (1928) 26 MIICH. L. REv. 618; Meyer, The Law of Coopcrativo Marketing (1927) 15 CALIF. L. REv. 85; Sapiro, The Lave of Coopcrative Marketing Associations (1926) $15 \mathrm{Ky}$. L. J. 1; Nounse, The Lecul Status of Agricultural Cooperation (1927); Montgoniery, The Cooperative PatTERN IN AGRICULTURE, (1929). For a thorough study of the history of the whole cooperative movement see Steen, Cooperatrve ILARkering (1923). On the general subject of guild socialism, see S. G. Hobson, NAtrowal Guinds and the State (1920); A. J. Penty, Post-Industrialisa (1922).

28. KY. ACTS (1922) c. $1, \S 28$. 
labor organizations. Yet the general attitude of the recent decisions of the Supreme Court indicates a more friendly disposition towards the farmer than has been manifested towards labor. ${ }^{20}$

Statutes have also provided for the enforcement of membership contracts by injunction and specific performance and by the recovery of liquidated damages for breach, and severe penalties both civil and criminal are to be imposed upon outsiders who attempt to interfere with the performance of these contracts. It has been consistently held that these provisions, in relation to farmer's associations lawfully engaged in cooperative marketing simply, do not impinge upon either the state or national anti-trust laws, and consequently are not offensive to the equal protection clause of the Fourteenth Amendment. As a result the marketing acts are functioning side by side with the anti-trust acts without friction. ${ }^{30}$

On the other hand there are limits of forbearance beyond which the cooperatives dare not go. Although the associations have a large amount of discretion with respect to how the agricultural

29. Contrast the early unfriendly disposition as expressed in the caso of Connolly v. Union Sewer Pipe Co., 184 U. S. 540 (1902), with the more recont case of Liberty Warehouse Company v. Burley Tobacco Growers' Cooporativo Marketing Association, 276 U. S. 71 (1928). In this case the Supreme Court in holding valid a Kentucky statute which gave certain exemptions to agricultural cooperatives, said, p. 96: "The opinion generally accepted-and upon reasonable grounds, we think-is that cooperative marketing statutes promoto the common interest." See, however, Frost v. Corporation Commission, 278 U. S. 515 (1929).

30. In Clear Lake Co-op. Live Stock Shippers' Association v. Weir, 200 Iowa 1293, 1301, 206 N. W. 292, 300 (1925) the court held that, “ . . a a moro selling agency is not, per se, a monopoly." In Northern Wisconsin Co-operativo Tobacco Pool v. Bekkedal, 182 Wis. 571, 593, 197 N. W. 945, 936 (1924) tho court stated that the marketing acts could be reconciled with the anti-trust acts as a reasonable classification, for " ... the legislature may clissify such agreements, condemning some and authorizing others, if there are reasonablo and proper economic, political, and social reasons for making the classification." In Tobacco Growers Co-operative Association v. Jones, 185 N. C. 265, 273, 117 S. E. 174, 178 (1923) the court held that the Cooperative Marketing Act, "... does not empower those who produce the raw material to create a monopoly in themselves." Of course the marketing acts, since they aro. tho later acts, would, if held repugnant to the state anti-trust acts, have the effect of repealing them. However, all of the decisions have been able to effect $a$ reconciliation. See also Dark Tobacco Growers' Co-operative Association v. Dunn, 150 Tenn. 614, 266 S. W. 308 (1924); Potter v. Dark Tobacco Growers' Co-operative Association, $201 \mathrm{Ky} .441,257$ S. W. 33 (1923); Louisiana Farm Bureau Cotton Growers' Co-operative Association v. Clark, 160 La. 294, 107 So. 115 (1926); Liberty Warehouse Company v. Burley Tobacco Growors' Cooperative Marketing Association, supra note 29. But compare Connolly v. Union Sewer Pipe Co., supra note 29, which is generally thought to be distinguishable. When restrictions on production are concerned see infra, noto 34 . 
products handled by them shall be marketed, still they may not unduly enhance the price of their commodities either by attempting to manipulate the market or by fixing a price unreasonably high.31 The Courts have more than occasionally gone out of their way to caution against such activities. ${ }^{32}$ Also a cooperative association may not enter into agreements with its members restricting the production of agricultural products. Section 6 of the Clayton Act and the Capper-Volstead Act contain no provisions which in any way authorize such action, ${ }^{33}$ nor do the cooperative marketing acts of the various states expressly grant to the association the right to attempt such regulation with their members. For the courts to discover the grant of such a right they would have to do so by rather far-fetched implication from some of the general language in the acts, and as yet they have been far from evidencing any such inclination. Whether, even if authorized by legislation, contracts between cooperatives and their members directed towards this end would be held valid in the face of the Fourteenth amendment, is not altogether certain. The word "liberty" in the due process clause has been variously defined by the courts. Restrictive covenants on the sale of a business or in connection with the relationship of master and servant have been upheld within certain limits. But a man cannot barter away his personal freedom, and the courts have often said that the right to follow any of the common occupations of life is an inalienable right, and no contract contrary to that end can be valid even though it has the sanction of the legislature. ${ }^{34}$ In the absence of legislative

31. People v. Milk Exchange, 145 N. Y. 267,39 N. E. 1062 (1895); Owen County Burley Tobacco Society v. Brumback, $128 \mathrm{Ky} .137,107$ S. T. 710 (1908) ; Dark Tobacco Growers' Co-operative Association v. Mrason, 150 Tenn. 228, 263 S. W. 60 (1923) ; List v. Burley Tobacco Growers' Co-operative Association, 114 Ohio St. 361, 151 N. E. 471 (1926). See also United States v. Trenton Potteries, 273 U. S. 392 (1927), where the Supreme Court held that an agreement among competitors as to the prices to be charged for the articles manufactured by them in and of itself constituted a violation of the Sherman Act regardless of the prices named.

32. See Ribnik v. MIcBride, supra note 1 , and cases cited therein.

33. The Capper Volstead Act expressly applies only to agricultural products already produced. It does not apply to production.

34. Miejer v. Nebraska, 262 U. S. 390 (1923); Oregon Growers' Co-operative Association v. Lentz, 107 Ore. 561, 212 Pac. 811 (1923); Truax v. Raich, 239 U. S. 33 (1915); of. the case of the laborer who resumes worl during a strilie in contravention of the orders of the union to which he has agreed, Brennan v. United Hatters of North America, 73 N. J. L. 729, 65 Atl. 165 (1906). See Warren, The New "Liberty" under the Fourtcenth Amendment (1926) 39 HARv. L. REv. 431; and Kales, Contracts to Refrain from Doing Businces or from Entering or Carrying on an Occupation (1917) 31 HANv. L. REv. 190. Even if such a statute should be held valid it might then have the consequence 
sanction contracts which have for their purpose the control of production have always been held void both at common law and under the anti-trust acts and the association responsible for them has been declared illegal as a combination in restraint of trade. No appellate court has yet directly considered such a contract in connection with a farmer's cooperative, ${ }^{35}$ but in several instances the courts have issued plain warning that it cannot be done, ${ }^{36}$ and in cases involving charges that cooperatives were monopolies operating in restraint of trade, it was deemed necessary to point out that the associations had not attempted to limit or reduce production. ${ }^{37}$ Indeed it is not altogether clear that even advice may be given regarding the

of repealing state anti-trust laws in toto as a consequence of the equal protection of the laws. However, this consequence might not be very serious in view of the extensive field of operation of the federal anti-trust laws. Soe Connolly v. Union Sewer Pipe Co., supra note 29; Beatrice Creamory Co. v. Cline, 9 F. (2d) 176 (D. Colo. 1925). See also the remarks of the court in Dark Tobacco Growers' Association v. Dunn, supra note 30, and Now State Ico Co. v. Liebman, supra note 1. Several state constitutions contain declarations against any form of monopoly. The following cases, however, declaro in sweeping terms that a classification of farmers as distinct from other classes is perfectly reasonable: Kansas Wheat Growers Association v. Schulto, 113 Kan. 672, 216 Pac. 311 (1923) ; Hollingsworth v. Texas Hay Associntion, 246 S. W. 1068 (Tex. Civ. App. 1923) ; Clear Lake Cooperative Livestock Shippors' Association v. Weir, supra note 30; Liberty Warehouse Co. v. Burley Tobacco Growers' Cooperative Association, supra note 29; Rifle Potato Growers' Association v. Smith, 78 Colo. 171, 240 Pac. 937 (1925); cf. also Heisler v. Thomas Colliery Co., 260 U. S. 245 (1922); American Sugar Refining Co. v. Louisiana, 179 U. S. 89 (1900). See Tobriner, supra note 27; Note (1926) 4 TEx. L. Rev. 382; Note (1926) 74 U. of PA. L. REv. 400.

35. There has been no case presented to the Supreme Court of the United States involving a cooperative marketing association in which this specinc question has been raised, but there are many cases involving commercial organizations which have been prosecuted under the Sherman Anti-trust Act in which the federal courts have held that agreements entered into by competitors engaged in interstate commerce operating to limit or restrict production violated that act. Addyston Pipe and Steel Co. v. United States, 175 U. S. 211 (1899); U. S. v. Keystone Watch Case Co., 218 F. 502 (1915); Gibbs v. McNeeley, 118 Fed. 120 (C. C. A. 9th, 1902); Contrast English law, English Hop Growers v. Deering, [1928] 2 K. B. 174, in which liquidated damages were awarded for breach of a contract to restrict production of hops.

36. Santa Clara Valley Mill \& Lumber Co. v. Hayes, 76 Cal. 387, 18 Pac. 391, 9 Am. St. Rep. 211 (1888); Cravens v. Carter-Crume Co., 92 Fed. 479 (C. C. A. 6th, 1899) ; List v. Burley Tobacco Growers' Co-operative Association, supra note 31; Washington Cranberry Growers' Associntion v. Moore, 117 Wash. 430, 201 Pac. 773 (1921). A Colorado trial court has held stuch a provision void.

37. List v. Burley Tobacco Growers' Cooperative Ass'n, supra note 31; Lee et al. v. Clearwater 'Growers' Association, 93 Fla. 214, 111 So. 722 (1027); Tobacco Growers' Cooperative Association v. Jones, supra note 30. 
advisability of reducing the acreage of a particular agricultural product. ${ }^{38}$ The act of Congress which created the division of cooperative marketing in the Department of Agriculture contains a provision which specifically authorizes farmers and their associations to exchange information and interpretations thereof concerning production and marketing. A state supreme court has held that an association may advise its members to grow less tobacco and to employ their land in the production of alfalfa. ${ }^{30}$ The court likened this action to suggestions which have been given by the Department of Agriculture. ${ }^{40}$

Even if the existing legal obstacles could be more or less successfully hurdled, it is far from certain that a satisfactory reorganization through cooperative associations could be projected. The practical difficulties, in view of the institutional pattern of agriculture, are manifold, and nothing short of such an at present chimerical project as compulsory pooling would be, perhaps, at all adequate. The control of production by voluntary agreements would involve a vast network of tangled and difficult relationships. The situation is much more complicated than even that which existed in our banking before the adoption of the Federal Reserve Act, when we had a decentralized system of over 30,000 individual banking units with unorganized reserves and subject to periodic collapses. A coordinated policy was impossible in view of the conflicts which existed between a sound national banking policy and what might be profitable to the particular banks.

In business and industry the value of association has been realized for a long time. Manufacturing corporations have made voluntary action effective even under the shadow of the anti-trust laws. However, their structure is very different from anything to be found in

38. Before two decisions of the Supreme Court of the United States in 1924 in cases concerning trade associations, it was not even certain that those pursuing the same industry could exchange information with regard to matters of common interest. Cement Mlanufacturers' Association v. United States, 268 U. S. 588 (1925) ; Maple Flooring Manufacturers' Association v. United States, 268 U. S. 563 (1925).

39. List v. Burley Tobacco Growers' Cooperative Association, supre note 31.

40. The basic rating and surplus price plans used by cooperative mill: marketing associations may have the indirect consequence of reducing or limiting production. However, there is no direct restriction on production since the members may produce as much milk as they wish, but the amount for which they will be paid on a fluid milk basis is restricted. Up to the present time the courts have not specifically considered the right of an association to control the marketing of milk under such a plan. The associations have come into courts a number of times, but in no case has the legality of their marlieting projects been directly considered. 
farming. ${ }^{41}$ The producing units which include also the marketing units are large and relatively few and they are pitted against many small buyers. Consequently a strong esprit de corps is not difficult to be achieved among the various concerns in any particular field, and there is also the simple instrument of consolidation. Demand can be made to respond to the stimulation of reduction in price, clever salesmanship and high-pressure advertising, and an easy ability to adjust supply to the market exists. The growing of crops, on the contrary, is a petty trade in which many are engaged, while the purchasers are large and few. Capacity to produce is too stubborn to be ruled by market requirements, and lowering of the price level does not eliminate the unnecessary sub-marginal undertakings. The easy facilities for entering the field invite newcomers whenever prices rise or other industries release surplus labor. The individual farmer has no reserves or specialized business advice to permit him to plan shrewdly for the future and at best his management is a hand-to-mouth affair. As in labor unions "scabs" are always an actual or potential source of danger to the functioning of the cooperatives. The "enlightened self-interest" of individual farmers does not always indicate that they should sustain the burdens as well as enjoy the advantages of organization. The cooperative pattern is opposed to all the traditions of farmers. Widely scattered as they are and cherishing a vaunted independence, it requires a very evil day to make of the individual a loyal supporter of the association, and he is only too ready to free himself from the group when he can see a chance for himself. The part of the minion has been far from heroic.

On the other hand, however, the mere fact that the counters with which the cooperative movement has gone to the tables have so far proved inadequate to beat the game is far from conclusive. Possibly the cooperatives may devise a new system of play or the legislature and the courts may give them more counters. One thing no doubt is clear, the cooperatives cannot hope to control production by the weapons of persuasion and the gentlemen's agreement which manufacturing organizations have used so successfully, and which is at present all that the law allows. In his occasional role of business man the farmer has proved himself too indifferent.

If in the cooperative movement is to be found a greater solution to the problems which assail the farmer, some prerogative right

41. For the suggestion that the solution to the farmers' problems lies in the reorganization of the producing unit along the lines which industry has followed in recent years rather than in legislative readjustments, seo KiLE; THE NEW AGRICULTURe (1932); Johnson, Relief from Farm Relief (Autumn, 1932) Yale REVIEW 52. 
must be bestowed upon it. A single cooperative marketing enterprise for each crop which should be given by the legislatures the power to enter into reasonable contracts with its members for limiting or reducing production, enforceable by injunction and by liquidated damages for breach, ${ }^{42}$ might win the day. However, in view of the wide-spread free-lancing which has played such havoc with all the more ambitious attempts of the cooperative movement, such an association will have to be given special railroad rates in the marketing of produce or some other generous mark of financial favor so that it would attract a sufficiently inclusive membership. ${ }^{13}$ Finally, as far as the legal issues are concerned, an additional measure of judicial tolerance would need to be counted on.14

\section{The Direct Regulation of Prices and Production}

The legal and political problems raised by the cooperative movement are almost insignificant in comparison with a program involving the direct regulation of prices and production by the government. Politically, farming has always been looked on as something with which the government should not directly concern itself. The arguments are so persuasive that usually it is not considered necessary even to mention them. The government may render incidental assistance to the farmer, but it must not enter the realm sacred to private direction. ${ }^{45}$ This vague and exalted atticude of mind has been giving way before the slow onslaught of constant maladjustment and the sudden shock of the depression. We have already witnessed the unhappy experimental efforts of the Farm Board, created by the late Republican administration, to stabilize agriculture by buying up the surplus. However, not only was the surplus too large for the Farm Board to take over but also there was nothing that the Farm Board could do with it, not even dump it abroad. The surplus remained almost as destructive a force in the domestic market as it had been in private ownership. A number of

42. Such measures have already been legalized in the enforcement of membership contracts for marketing. The decisions of the courts indicate that these measures are no unfair classification in violation of the Fourteenth Amendment, and so leave the anti-trust laws unaffected. See note 30, supia.

43. Consider also the same project involving compulsory pooling, now politically and constitutionally impossible.

44. See notes 32, 34, supra.

45. England, for example, as does most other European countries, guarantees the price of many food products. However, the problem of the European countries is that of attaining self-sufficiency, not that of a surplus. Consequently their price-fixing legislation is designed expressly to encourage production. See Beveridge, British Food Contror (1928). 
other proposals have been more or less seriously considered by Congress in recent years, such as the McNary-Haugen (the equalization fee) and the export debenture bills. The philosophy behind these projects has been to devise a system of giving a tariff benefit to farmers, and thus equiparate their position to that of manufacturers. The process of equiparation would be accomplished by means of a bounty. ${ }^{46}$ Among other objections against them, it was urged that the bounties would encourage farmers to increase production with the result that prices would fall and the situation would be even worse than before. Whether this would have been true or not, at least all of the proposals would have involved dumping surplus crops abroad. No doubt this would have led sooner or later to the levying by foreign countries of an anti-dumping tax against our exports. And in any event the Farm Board experiment has taught us that it is simply no longer possible to dump surpluses. The utter failure of these cautious attempts to apply an anaesthetic to farming has finally created a strong sentiment in the agricultural districts demanding that the legislature undertake the fixing of a minimum price and that the United States fall in line with the Europenn countries which have already assumed this function. ${ }^{47}$

Legally, a frontal attack by direct government regulation would mean conflict with the conventional notions of "industries affected with a public interest." The Supreme Court has recited time and time again, but by way of dicta only, that ". . . at least in the absence of grave emergency, . . . the fixing of prices for food or clothing . . . whether minimum or maximum, is beyond the

46. The equalization fee plan provided for marketing agreements with cooperative associations, or corporations created and controlled by thom, by which they would hold part of the commodity off the market during a specified period, costs to be paid out of a stabilization fund. This fund would bo built up through the proceeds of an equalization fee assessed by the board on each marketed unit of the commodity, to be paid on the transportation, processing, or sale of such unit. The export debenture method of price control provided for issuance of debentures by the Secretary of the Treasury to exporters of the commodities affected in an amount equivalent to one-half the rate of duty on imports of such commodities. Export debentures would be receivable at their face value in payment of import duties or might be redeemed at $\mathfrak{a}$ slight discount by the Secretary of the Treasury.

47. See the proposals of Senator MCAdoo and former Senator Brookhart which have been indorsed by a number of farming organizations. Senator McAdoo has prepared a bill providing for the fixing of minimum prices for a number of agricultural products which he has announced that he intends to introduce in the present Congress. To avoid any difficulty with intor and intra state commerce classifications the proposals contemplate also the legislative cooperation of the various agricultural states. 
legislative power." ${ }^{48}$ However, judicial responses to questions which have not been framed, like shouting in an unexplored canyon, indicate very little of the contours and figurations which lie ahead. These responses have all been based on the assumption that the natural market, blessed by the invocation of laws against trusts, monopolies, conspiracies and combinations in restraint of trade, determined price and production to the greatest well-being of buyer, seller and the community at large. But let that assumption be challenged by the Legislature in a time of falling business and when it is recognized that natural economic forces may work disorder and disaster, and the question would need to be approached not as a matter of past attitude but as an aspect of a necessarily new public policy. No doubt it would be no light task to convince all the members of the Supreme Court that the structure of industry according to law is something of a castle in the air. But a strong minority has already indicated that it is convinced and enough others have not yet said that they are not open to conviction.

Affectation with public interest has proven itself before now to be a highly receptive concept and one which permits of graceful accommodation to whatever new attitude the court may bring to its problems. In the minds of the majority of the judges at the present time there is back of the phrase a sharp cleavage between two radically different orders of being which divide industries between them and leave no other possibilities with which to conjure: the competitive and those where for one reason or another competition does not work freely and so does not give to buyers and sellers the protection which their interests require. In the competitive order, restraint of price, "the heart of the contract," is unnatural, a violation of economic laws and sure to do more harm than good.40

However, this easy dichotomy of a vast interlocking industrial culture which hardly antedates the century has been fixed and hard in Supreme Court decisions for not more than a decade. In the process of analysis the Court took no notice of the presence of very great maladjustment, interdependent industries, the intricate prob-

48. Ribnik v. McBride, supra note 1 , at 357 . See note 2 , supra. Valuable recent discussions on legislative price fixing are Powell, Stato Utilitics and the Supreme Court 1922-1930 (1931) 29 MIICE. L. REv. 811; Hamilton, Affcctation with Public Interest (1930) 39 YALE L. J. 1089; MrAllister, Lord Hale and Business Affected with a Public Interest (1930) 43 Harv. L. REv. 759.

49. During the Revolution eight of the thirteen states passed statutes fixing the price of most commodities. See Note (1920) 33 Hanv. L. REv. 838. And for many years after that the price of bread was regulated by statute in South Carolina and Maryland. 5 STAT. OF S. C. 186 (1791); S. C. ACTS OF AssentBly, 1791-1794, p. 88; Mid. LuAfS (1789) c. 8, § 2, Herty's Digest of THE LAWS OF IIARYLAND (1799) 250. 
lem of unruly capacity for supply, "producer's disadvantage" (not less important for the community than "consumer's disadvantage"), and it was not faced with the task of salvaging industrial wreckage from a depression which is a gigantic commentary on the failure to. bring supply and demand to equality. The endless variation of business structure and control do not allow of the sublime simplicity of a rule of two. Indeed, in the agony of conflict with the realistic situations in which it has attempted to project the doctrine, the Court has not only confessed to bewilderment, but has almost presented it in the phraseology of a riddle, the answer to which its propounder does not know.50 Affectation with public interest is now an established category of fact but any attempt at analysis would be futile. It is not difficult to sympathize with Mr. JusticeHolmes who rejects the concept as "little more than a fiction." of

That farming is not a natural monopoly is no doubt clearer than the contrary; therefore in the casual thoughts bestowed upon farming by the Court it has consistently been put in the category of industries subject only to regulation for the maintenance of the competitive market. No one can conjecture what weight the Court is now ready to give to the evidence that agriculture is sui generis, to be defined, if definition is wanted, as an instance of "producer's disadvantage" where competitive conditions cannot be depended upon: to establish rightful prices for farm products or to limit production in accord with maximum economy. Whether or not it is too late to substitute for the doctrine of "public interest" as the test for pricefixing, ${ }^{62}$ the pragmatic suggestion of Mr. Justice Stone in Tyson $v$. Banton ${ }^{* 3}$ is not conclusive, for the classification of industries af-

50. See Mr. Justice Sutherland in Ribnik v. McBride, supra note 1 at $355_{\alpha}$ "Is the business one 'affected with a public interest', within the meaning of that phrase as heretofore defined by this court? As was recently pointed out. in Tyson \& Bro. v. Banton, . . . the phrase is not capable of exact definition; but, nevertheless, under all the decisions of this court from Munn v. Illinois, $\ldots$ it is the standard by which the validity of price-fixing legislation, in respect of a business like this here under consideration must be tested." $C f$. Williams v. Standard Oil Co., 278 U. S. 235, 239. Mr. Justice McKenna in German Alliance Insurance Co. v. Kansas, 233 U. S. 389,406 finally snid: "We can best explain by examples." See also Mr. Chief Justice Taft in Wolff Packing Co. v. Court of Industrial Relations, supra note 1.

51. Tyson \& Brother v. Banton, supra note 1.

52. For a suggestion that affectation with public interest is not tho conclusive test for price fixing, consider carefully Tagg Bros. \& Moorhend v. United States, 280 U. S. 420 (1930), where Mr. Justice Brandeis spoke for a unanimous court, and O'Gorman \& Young v. Hartford Fire Insurance Co., 282 U. S. 251 (1931).

53. "An examination of the decisions of this court in which price regulntion has been upheld will disclose that the element common to all is the existence. 
fected with a public interest has not yet been finally made, and in any event the application of a principle that has been written can be made less automatic." A rule which so far has been applied chiefly to the appendages of other businesses may take on a distinctive form when considered in relation to an immense basic industry. Nor might the Supreme Court care to assume the momentous responsibility of vetoing a legislative act of more than ordinary importance, and to undertake itself in the isolation of the legal cloister the fashioning of rules for what has been proclaimed by the Legislature as the coming of a new order. If the Court did not care to go too deeply into the stuff of its mysterious creation, an easy as well as persuasive way out is at hand with the assistance of the word "emergency." s5

In a completed form the mechanics of a scheme for price-fixing would be, if anything, more complicated than those involved in an effective reorganization of the cooperative movement. Obviously a minimum price could only be established for the share to be sold in the domestic market. Consequently in those instances where overproduction is possible the government would need to fix the amount

of a situation or a combination of circumstances materially restricting the regulative force of competition, so that buyers or sellers are placed at such a disadvantage in the bargaining struggle that serious economic consenuences result to a very large number of members of the community." Supra note 1, at 452. See also the dissent of Mrr. Justice Stone in Ribnik v. MrcBride, supra note 1, at 359: "Under the decisions of this court not all price regulation, as distinguished from other forms of regulation, is forbidden. ... As I read those decisions, such regulation is within a state's power whenever any combination of circumstances seriously curtails the regulative force of competition, so that buyers or sellers are placed at such a disadvantage in the bargaining: struggle that a legislature might reasonably anticipate serious consequences to the community as a whole."

54. Mr. Justice Brandeis in his elaborate dissent in the Netb State Ice Company case said (285 U. S. at 302-303) : "In my opinion, the true principle is that the state's power extends to every regulation of any business reasonably required and appropriate for the public protection. I find in the due process clause no other limitation upon the character or the scope of regulation permissible."

55. See Block v. Hirsh, 256 U. S. 135 (1921) where a rent law, passed as a war measure was held constitutional; Wilson v. New, 243 U. S. 332 (1917) where the Adamson act giving to certain railroad employees an eight hour wage equivalent to their previous ten hour wage was held valid on the fround (inter alia) of an emergency. In the Ncw Statc Ice Company case MIr. Justice Brandeis said (285 U. S. at 306): "The people of the United States are now confronted with an emergency more serious than war. Mifisery is widespread, in a time, not of scarcity, but of overabundance. The long-continued depression has brought unprecedented unemployment, a catastrophic fall in commodity prices, and a volume of economic losses which threaten our financial institutions." 
of produce which is to be consumed domestically. ${ }^{\circ 0}$ Consequently also, in order to insure that every farmer would have a chance to participate in the benefits of the fixed price, the government would need to issue to individual farmers quotas for the amount of produce which each might place on the domestic market. The elimination of the related evils of low prices, destructive surpluses and wasteful overproduction would be adequately contemplated and no doubt with proper administration could be sufficiently achieved.

Whether or not, however, the sacrifice of flexibility and of all natural economic forces should be allowed to weigh heavily against the attempt to control agriculture directly by legislative action is a formidable question. The necessity of a unified control and general oversight for farming is great, but to what extent is it advisable to have particular decisions left to those most closely concerned? Simplicity and flexibility, the absence of an over-complex mechanism, the avoidance of police supervision, and the linking up of the general end with immediate individual interest are elements which are not often prominent in plans for close government supervision. Would a more circuitous type of regulation like that for example introduced to American law by the Federal Reserve Act ${ }^{67}$ be preferable to such a direct control as is represented by the activities of the Interstate Commerce Commission? This issue describes in part the process of creation of another proposal.

\section{Control of Production by Means of the Taxing and Spending Powers of Congress}

A second type of proposal for farm relief which like direct governmental regulation is hopeful of bringing permanent order into the

56. In a special report on legislative recommendations, supplementing its third annual report to Congress, the Federal Farm Board held that the following principle had been demonstrated by experience to be essentinl for effective relief: "Prices cannot be kept at fair levels unless production is adjusted to meet market demands. ... Any method which provided higher prices and did.not include effective regulation of acreage or of quantities sold, or both, would tend to increase the present surpluses and soon break down as a result. To be of lasting help, any plan must provide a system of effective regulation, so that our millions of farmers can plan and adjust thoir production on a dependable basis, instead of competing blindly with each other."

- 57. Standards in the Federal Reserve System are maintained by the persuasion and constraint of rediscount and open market policies upon mombor banks, and not to any great extent by directly enforceable duties. Ever since its existence the act has been suggestive of an easy control with very littlo direct interference which might with necessary modifications be used for other ontorprises. See Westerfierd, Banking Principles and Practice (1928). 
affairs of agriculture is the Voluntary Domestic Allotment Plan.ts Its distinguishing characteristic, marking it as a radical departure from the equalization fee and the export debenture schemes, ${ }^{53}$ is that it intends to pay the farmer a bounty on produce sold in the domestic market on the condition that he voluntarily reduce acreage, thus regulating both price and production. For this reason it represents a plan which if practical and effectively managed could be made to counteract the ills of the present situation. The bounty is to be collected by an excise tax on the processing of that part of the products which is consumed in the United States and is to be paid over to those farmers who voluntarily limit their acreage in accordance with the plan. Acreage quotas for individual farmers would be based on their average crop over a period of years. The tax and bounty are to be adjusted so as to make the price received by the farmers as valuable relative to all other goods as it was before the war. ${ }^{60}$

Under this plan production would be controlled not by direct sanction but by financial inducement. If a farmer chafed at the restraints imposed the only penalty for non-adherence to the designated quota would be sacrifice of the bounty. If he conceived, from the complexion of the market, that effective demand for his crop would make profitable more extensive production, individual judgment not governmental edict would be the final arbiter. Whether this potential (and perhaps hypothetical) flexibility would be economically desirable or whether its actual realization would in considerable measure thwart the larger objectives is an issue which has borne much argument. In any case the practical desirability of the allotment plan depends in large measure upon this two-edged prerogative of individual initiative and liberty of action.

58. The Voluntary Domestic Allotment Plan has had a number of changes and modifications since its inception. In its latest available forms it has been known as the Norbeck-Hope Bill (SEIr. REP. No. 4985, 72d Cong. 1st Sess., and H. R. REP. No. 12918, $72 d$ Cong. 1st Sess.), the Knight Bill and the Jones Bill (H. R. REP. No. 13399, 72d Cong. 2d Sess.) which was passed by the House January 12, 1938. The original plan seems to have been a composite of plans devised by the late Walter J. Spillman, Professor John D. Black of Harvard, and Professor M. L. Wilson of the Miontana State College. Miost of the discussions of its applications concerned cotton, wheat, hogs, rice and tobacco. The scheme of the plan is generally conceded to conform more nearly than any other to the six points laid down by Governor Roosevelt in his Topelsa speech.

59. See note 46 , supra.

60. Many friends of the measure are willing to admit that pre-war conditions present no "scientific principle" by which the amount of the tax should be determined, but rather that it should be estimated by economists on the basis of general conditions today and the actual needs of farmers. 
The reason, however, for the incorporation of this particular type of regulation in the allotment plan represents also an attempt to avoid the Constitutional difficulties involved in the fixing of prices and production by the government. The taxing clause has often proved to be an effective means to a variety of ends, and the enactment of taxes and duties for purposes in fact alien to the financing of the government is now regarded as an orthodox feature of the law. Nevertheless two constitutional problems, are suggested by the allotment plan: (1) whether the tax levied is actually a tax or a regulatory police measure; (2) whether a federal tax may be levied or appropriations made by Congress from the general revenue for the purpose of a bounty to the farmers.

The grant of the national taxing power is contained in article I, section VIII, clause 1: "The Congress shall have power to lay and collect taxes, duties, imports, and excises, to pay the debts, and provide for the common defence and general welfare of the United States; but all duties, imports, and excises shall be uniform throughout the United States." It is, characteristic of the constitutional delegations to Congress, so uncertain and ambiguous that when it must be charted there is likely to enter into the result a measure of personal preference. Along with the postal power and the war power it has a more generous sweep than the usual federal powers and it is not so intimately concerned with the question of what is sacred to the domain of the state. ${ }^{61}$

In 1922 the Supreme Court, departing from what had seemed to be the previous doctrine, ${ }^{02}$ held that it could look through the form of a taxing statute if it was apparent on its very face that it was not intended for purposes of revenue but for purposes of regulation. ${ }^{03}$ An

61. The war powers pay little respect to nice problems of state and national control. Excise taxes and the strongly progressive rates of the national estate and income taxes may influence rights which are exclusively within the direct control of the states.

62. Before the Child Labor Tax Case and Hill v. Wallace there was much authority for the proposition that the court could not search out the motive or purpose of Congress in imposing an excise tax. In re Kolloch, 165 U. S. 526 (1897) ; McCray v. United States, 195 U. S. 27 (1904) ; United States v. Doremus, 249 U. S. 86 (1919); Veazie Bank v. Fenno, 8 Wall. 533 (U. S. 1869); Flint v. Stone Tracy Co., 220 U. S. 107 (1911).

63. The Child Labor Tax case (Bailey v. Drexel Furniture Co., 259 U. S. 20 (1922)) held unconstitutional a federal statute which levied an annual excise tax equivalent to $10 \%$ of the entire net profits on every person "using child labor" in a mine or manufacturing establishment for more than eight hours a day or six days a week or before the hour of six o'clock anto moridian during any part of the taxable year. In Hill v. Wallace, 259 U. S. 44 (1022) a federal tax was also held unconstitutional. The act in question imposed $a$ tax of 20 cents a bushel on all contracts for the sale of grain for future delivery, 
excise tax that is in point of fact a measure of regulation may be invalidated if it is not limited to interstate or foreign commerce. However, if it should be held that a taxing statute is in substance and truth an exercise of the taxing power, whatever incidental effects it may have towards the regulation or suppression of business enterprises is immaterial.

Thus we start with the proposition that what is in form a tax may be a police regulation so alien to any purpose of financing the national government as to be outside the taxing power vested in Congress. The Constitution does not bestow on Congress complete power of regulating anything it wishes provided only that it enforces its behests by threatening to tax violators. However, the tax on processors proposed in the allotment bill is, if considered alone, obviously a fiscal and not a regulatory enterprise. The tax itself contemplates the raising of money and not the regulation of the processing business. There is no difficulty in distinguishing Hill $v$. Wallace and the Child Labor Tax case. ${ }^{64}$ A penalty is not being imposed on processors for departures from conduct prescribed for their industry. On the other hand an unsympathetic court could, without any great difficulty, largely extend the principle of those decisions to invalidate taxing statutes which contemplate police regulation not by the tax itself but by the funds to be derived from the tax. ${ }^{60}$

but excepted sales on boards of trade designated as contract markets by the Secretary of Agriculture, on the fulfillment by such boards of certain requirements set forth in the act.

64. For a discussion of some further issues which might be involved, see note 90 , infra.

65. It is submitted, however, that this reasoning would be unsound logically. It should be observed that no question arises of interference with the rights of the states reserved by the Tenth Amendment. That amendment, although it may have some political significance, sets up no criterion for deciding as to whether or not a power has been given to Congress. It must be established independently of the Tenth Amendment that the constitution does not give the power to the federal government. But see Hammer v. Dagenhart, 247 U. S. 251 (1918) ; Child Labor Tax case, supra note 63; Hill v. Wallace, supra note 63. Of course in any event it could hardly be argued that this is an interference with the Police Power of the States since under the Police Power the states have no right to regulate the production or price of food or clothing. A clearly prohibitive tax might possibly be held invalid under the due process clsuse. "However, no federal tax has thus far been held to be a violation of the Fifth Amendment and there are several intimations in the opinions of the Supreme Court that the Fifth Amendment does not limit the taxing power of Congress. These, however, are offset to a degree by the recognition that a sa-called tax may be so atrociously outrageous as not to be a tax but an arbitrary exaction. Thus the situation seems to be that the Fifth Amendment does not limit the federal taxing power as the Fourteenth Amendment limits the taxing power 
This fact that the proceeds of the tax are designed not for the administration but for the farmer, that the defeat of the bill would score the farm bloc, not the financiers of the government, raises also the second question: What are the purposes for which Congress may raise money by levying an excise tax? ${ }^{\circ 0}$ The clause in article I, Section VIII provides that Congress may levy taxes "to pay the debts and provide for the common defence and general welfare of the United States." How is the power to appropriate affected by the sweeping term "to provide for the general welfare"? Can Congress exercise its power to levy a tax for a specific purpose (or to make appropriations from the general fund) only in furtherance of its exercise of powers otherwise enumerated, or is the permissible disposition of governmental revenue unrestricted save by the literal meaning of "the general welfare"? ${ }^{\mathrm{ct}}$

This resurrects a constitutional question which once concerned mightily our earlier statesmen and was elaborated in ways that now often seem labored and imaginative. Strangely enough the Supreme Court has never rendered a decision on the point. The question has simply never been directly considered. The verdict must be drawn from the practice of Congress, the opinions of men in public station and commentators on the Constitution, the persuasion of some dubious dicta, and such arguments of syntax, logic, history and policy as may influence the Court.

The issue has generally arisen with reference to the power of Congress to provide for internal improvements, although after the Kentucky and Virginia Resolutions it became involved for a time with the general doctrine of State's rights. Hamilton and Madison had earlier traced the issue in the Federalist, Hamilton contending

of the states, but that there is still a limit of reasonableness boyond which Congress may not go." (1922) 1 N. C. L. REv. 68, n. 27.

66. In considering an issue of constitutionality a court must not go beyond inference drawn from the statute itself. This seems to be the doctrine laid down in McCray v. United States, supra note 62, as interpreted by the Child Labor Tax case, supra note 63. See also Veazie Bank v. Fenno, supra noto 62. This consideration, however, hardly arises in the Allotment bills proposed thus far, since all of them include the tax and the appropriation in the same measuro. If, however, the tax and the appropriation were made separate pieces of legislation as is proposed in the program for farm relief placed before Congress by the president (discussed infra), could the processors attack the validity of the tax as being a regulatory measure? All of the authorities apparontly hold that they could not.

67. For the contention that the spending power of congress is unrestricted by virtue of the effect of the "general welfare" clause see Corwin, the Sponding Power of Congress (1923) 36 HARv. L. REv. 548. On federal subsidies to tho states see MacDonald, Federal AID: A Study of the American Subsidy SYSTEM (1928). 
for the broader interpretation ${ }^{c s}$ and Madison holding that the general welfare clause is limited by the other powers of Congress. ${ }^{c 0}$ In 1791 in his Report on Manufactures ${ }^{70}$ Hamilton restated his position and argued that "the only qualification of the generality of the phrase in question which seems to be admissible, is this, that the object to which an appropriation of money is to be made must be general and not local-its operation extending in fact, or by possibility, throughout the union, and not being confined to a particular spot." In general the presidents from the time of Aionroe on seem to have accepted the views of Hamilton except during the period immediately before the Civil War when state's rights principles were looked on with favor by all parties. To this large consensus of opinion must be added the high authority of Story.71

The conclusions to be drawn from the procedure of Congress in making appropriations is a more difficult matter. ${ }^{72}$ An examination of appropriations for internal improvements show that they have in more recent times been rested on some other specific power contained in the Constitution, such as the interstate commerce, the postal and the war clauses, and not on the "general welfare" provision. Such justifications, however, had not occurred to Congress in the earlier period, and "general welfare" was then relied upon. ${ }^{33}$ Thus, in 1792,

68. 1 FEDERALIST (1894) Nos. 30,34. For an account of the attitude of the convention towards the clause, see FarRand, Records of the Federat CoNVENTION (1907).

69. I FEDERALIST (1894) No. 14. For his later writings on the subject, see "Report on the Resolutions," 6 Writings (Hunt ed., 1910) 354-356, and the "Veto Mlessage of 1817," 1 Richardson, Miessages and Papens of the PresiDENTS (1898) 584-585. See also 1 Benton, Abrmgarent of the Debates CF CoNGress (1857) 350.

70. 4 WORKS (Lodge ed., 1898) 70, 151. Mradison's view was supported and emphasized by Jefferson, as stated in his "Opinion on the Constitutionality of a National Bank" (February 15, 1791) 3 Wrimngs (Memorial ed.) 147-149. Washington, in his final message to Congress indicated that he believed that Congress possessed the widest discretion in taxation and appropriation by recommending the establishment of a national university, manufacturers on public account and encouragement to agriculture. 1 RicharDSON, LIESSAGES and Papers of the Presments (1898) 201-202.

71. Story, Commentaries on the Constitution of the UNited States (1833) $§ \S 905-930,958-991$.

72. As to the weight which the judiciary should give to the opinions and actions of other departments, see Stuart v. Laird, 1 Cranch 299 (U. S. 1803); Bank of United States v. Halstead, 10 Wheat. 51, 63 (U. S. 1825); United States v. Healey, 160 U. S. 136 (1895); United States v. Midwest Oil Co., 286 U. S. 459 (1915) ; Downes v. Bidwell, 182 U. S. 244 (1901).

73. For an account of the history of internal improvements in the early period see Monroe's, "Views of the President of the United States," 2 RicinnDsoN, Miessages aNd Papers of the Presidents (1898) 144. But these appropriations 
an appropriation from the general funds was made in order to pay a bounty to the cod fisheries. ${ }^{74}$ The sums which have been voted from the general funds for the encouragement of agriculture, the public health, education and the geological survey ${ }^{75}$ likewise present constitutional precedents for the independent nature of the "general welfare" clause.

The case law offers at best an opportunity for the use of generous comparisons and easy distinctions. The Supreme Court has not been slow in availing itself of jurisdictional matters to shelve the substantive problem. In all of the cases where the issue was squarely presented the Court was able to reserve the question. ${ }^{76}$ More or less pertinent analogies and dicta may, however, be picked up wholesale without particularly contributing to a determination of the problem. ${ }^{77}$

were in most instances not made from tax funds but by grants of land or from funds derived from the sale of land, and as to such grants and appropriations it is obvious that they are authorized by Article IV, section III, clause 2. Still thoy amount to valid constitutional precedents notwithstanding.

74. 1 Benton, supra note 69 , at 346 .

75. The following are some of the various bureaus and boards for which appropriations have been made: The Weather Bureau, the Public Health Service, the Geological Survey, the Bureau of Education, the Bureau of Mines, the Bureau of Animal Husbandry, the Bureau of Plant Industry, the Bureau of Soils, the Bureau of Markets, the Bureau of Fisheries, the Bureau of Labor Statistics, the Children's Bureau, the Smithsonian Institute.

76. Field v. Clark, 143 U. S. 649 (1892). In 1890 Congress provided a bounty to sugar growers in lieu of a protective tariff, and when this was later repealed an act directed the payment of bounties already earned. The bounty law had not been questioned by any court or officers of the government; and had been relied upon by sugar producers in investing large sums. The last act was held valid, regardless of the validity of the original bounty, United States v. Realty Co., 163 U. S. 427 (1896) ; Allen v. Smith, 173 U. S. 389 (1899). Tho Maternity Act of 1921 provided for the promotion of the welfare and hygieno of maternity and infancy, and authorized the appropriation to be apportioned among such of the states as shall accept and comply with its provisions. It was held that in the particular instances there was no interest sufficient to support a contest of validity. Massachusetts v. Mellon, 262 U. S. 447 (1923).

77. See for instance United States v. Gettysburg Electric Ry., 160 U. S. .668 (1896); Dayton-Goose Creek Ry. v. United States, 263 U. S. 456 (1924); California v. Central Pacific Ry. Co., 127 U. S. 1 (1888); Loughborough v. Blake, 5 Wheat. 317 (U. S. 1820); Ward v. Maryland, 12 Wall. 418 (U. S. 1870); United States v. Boyer, 85 Fed. 425 (W. D. Mo. 1898); Mayor of Now York v. Miln, 11 Pet. 102 (U. S. 1837); In re Rahrer, 140 U. S. 545 (1891); Kansas v. Colorado, 206 U. S. 46 (1906); Lane County v. Oregon, 7 Wall. 71 (U. S. 1868); Barbier v. Connolly, 113 U. S. 27 (1885); Keller v. United States, 213 U. S. 138 (1909); Lowell v. Boston, 111 Mass. 454 (1873); Loan Association v. Topeka, 20 Wall. 655 (U. S. 1874); Northern Liberties v. St. John's Church, $13 \mathrm{~Pa} .104$ (1850); In re Kollock, supra note 62; McCray v. United States, supra note 62; In re Rapier, 143 U. S. 110 (1892); Child Labor Tax caso, supra noto 63; Hill v. Wallace, supra note 63. 
With such a respectable body of material which could with judgment be marshalled either for or against, and with a Constitution that has lent itself to striking variance of opinion as to its construction, he would indeed be a bold prophet who would undertake to predict the outcome. Constitutional law is sure to be influenced by ideas of statecraft, and the decision that a power does or does not exist may have been persuaded by conviction as to its wisdom. The scheme itself is strange and new to the traditions of our government. It concerns a submerged class whose welfare has not been pre-eminent in the interpretation of legal doctrine. That behind this proposal is paramount public need in a world of accomplished facts with which we must come to the best terms possible must be granted. In such cases the function of the Supreme Court is to accredit and direct the desirable phases of the flux of economic events. Whether in the performance of this task which the Court has wittingly or otherwise assumed, it will be ready to go beyond the superficial facts of the case to the place of maladjustment and to the envisaging of meaning for the future, is necessarily a matter of guesswork. Probably no one will now maintain that the profound duty of the Court is to maintain a discreet ignorance of the outside world. But where the judgment is not clear as to what are the best terms possible, where there are other potential lines of development, too much judicial objectivity may not be desirable. At the same time one must recognize that although the Supreme Court has undoubtedly discarded much of its faith in blind competition and the unassisted functioning of the economic mechanism, still the older traditions of romantic liberalism and hardy American individualism have not been eaten away by the pressure of industrial change. In any specific instance the Supreme Court will no doubt attempt to steer a course which does not tend too much towards either disastrously uncontrolled production or excessive governmental participation in industry.

Appraisals of this plan have been brought forth in all the Homeric varieties of praise and censure that might have been expected. To its advocates the plan assures immediate alleviation for widespread suffering, an easy way of controlling a stubborn industry and general assistance in the rehabilitation of the country. To its critics the plan is a daring economic experiment with all the dangers of class legislation and industrial protection and all the complexities of state socialism. To more moderate viewpoints the plan represents a suggestion for improving future performance by a new method of regulation that eliminates the disadvantages common to schemes for direct governmental control, but which cannot by any stretch of confidence be guaranteed never to stray from the straight road. No doubt the administration of the allotment plan would not be simple 
or easy. There would be opportunities in plenty for blundering, petty favoritism and corruption. Congress seems determined to eliminate the incentives and administrative devices used in the original version of the plan as presented in the Norbeck Hope Bill which would make for a decentralized local control. In the Jones Bill, the form in which the allotment plan passed the House of Representatives, the entire regulation is thrown directly into the hands of federal agents who fix the quota for the individual farmers and pay the bounties ${ }^{78}$ upon a finding that the farmer has reduced his acreage. No doubt the agents will not be entirely free from the pressure of local opinion and of even less commendable influences. ${ }^{70}$ However, one may recall that we accept the mere affidavit of a man on his income tax and there has been no compelling evidence of any considerable evasion. ${ }^{80}$

78. In the form of certificates redeemable at the treasury.

79. In the original plan, it was provided that the Farm Board should determine what the domestic consumption of, let us say, whent, was for a crop year. The Board was then to allot to each state a quota in proportion to the average acreage planted in that state for the past five years multiplied by the average yield per acre for the past twenty-five years. That quota flxod the total number of bushels of wheat on which any state could draw the adjustment charge from the treasury. In other words, the plan fixed the oxact amount beyond which no state could go in calling upon the Treasury. Whon the state's quota was fixed, a state committee allotted to each county its proportionate part of the quota. In each county a committee allotted to each farmer his proportionate share of the quota. Under the Jones Bill an agent appointed by the Secretary of Agriculture pays the money to the farmor when the agent is satisfied that the farmer has reduced his acreago 20 per cont. If the farmer cheats the agent, the Treasury, and not his neighbor, suffors.

80. Other objections to the domestic allotment plan: (1) "Any attempt to control the operation of the laws of supply and demand in a state of froo competition is unsound in principle." In answer to this, it may be stid that reliance on the competitive elimination of high-cost men and high-cost ncres, has also its drawbacks. It means wholesale bankruptcies. It has the destructivo wastefulness of other uncontrolled natural laws. Letting the surplus problom solve itself by progressive calamity is not creditable in a scientiflc ago. (2) "The plan is a gigantic sales tax on necessities and consequently would bo most heavy on those with low incomes." On the other hand, however, it is urgod that consumers are already buying their food products much cheaper than any other group of products they purchase. According to the Bureau of Labor Statistics (in November, 1932), since 1926 the decline in retail prices of food has been one and one-half times as great as in any other group of products. In increasing these prices to consumers, this plan does not place an unfair tax upon them, but merely restores to farmers part of that which they havo lost through the price inequalities brought about during the depression. Even after adding on the adjustment charges, retail prices of farm products would still be lower than those of any other group. Furthermore, the fall or riso in farm prices is not greatly reflected in retail prices. The price, for exnmple, of flour is a very small part of the price of bread. It has been reliably estimated 
The suggestion which the Domestic Allotment Plan contains for an easy method of control is now in the process of being developed in a number of other ways. The so-called Farm Land Rental Plan represents another proposal for indirect regulation of production by means of the taxing and spending powers. Under this plan the federal government would lease the land which is not needed in the production of goods for domestic consumption. The funds required to meet the rental costs would be raised by a tax on processors similar to that proposed for financing the allotment plan. The plan contemplates that since the lowest bid (and therefore presumably the poorest) land would be leased, it would be the actual sub-marginal land which would be eliminated. However, in comparison with the allotment plan the scope of operation of this scheme seems manifestly inadequate. The program of farm relief placed before Congress by President Roosevelt involves the use of both measures, either as supplementary or alternative, in the discretion of the Secretary of Agriculture. The Secretary of Agriculture would also be given almost complete. discretion in working out the details of administration. He would determine the commodities to be included in the program, how large a tax within certain limits to impose upon processors, and if he finds that the tax discourages consumption of one commodity, he may impose a tax on competing products. Such enormous centralization of power and responsibility which rarely

that the Allotment Plan would only raise th price of bread one cent a loaf. (3) it is obvious also that if the plan is not applied to all agricultural produets it may be difficult to apply it to a selected few. For cotton and wheat the situation is comparatively simple. However, for pork the consequent increase in price might have serious consequences since a scheme of control cannot be so simply patterned about pork alone in view of the easy competition of other meat products. (4) It may be argued that production cannot be controlled by controlling acres, since output depends also on the weather and on insect pests and plant diseases. Locally this is true. But taking the country as a whole production is surprisingly uniform. In the last 25 years the average yield of wheat per acre has been 14.5 bushels. The highest yield was 17 bushels and the lowest 12.2 bushels, a maximum variation above the average of only $17 \%$ and below the average of 16\%. See ANNUAL Report of SECretary of Agriculture (1931) 29. In most of these years the yield was much closer to the average. The volume of production, taking the country as a whole over a period of years, is primarily determined by man rather than by nature. (5) Whether this plan if put into operation might not prove a stronger political temptation than our legislators could resist is perhaps the most serious question. Once the plan is enacted Congress would be under constant compulsion to maintain or raise the bounties without regard to the actual conditions of agriculture and to apply them to agricultural products already well controlled, much as has happened in the case of the tariff. The danger of a vested agricultural interest, stronger politically than our present manufacturing interest, might prove to be a very real one. 
has been given to any American official seems eminently justified in view of the intricacies of the issues which will be involved and the necessity for decisive action. ${ }^{81}$

\section{The Control of Production by Means of Debt Readjustment.}

The above proposals make no attempt directly to cope with the immediate and accelerating menace of farm debts. The solution of this problem, however, is too critical to be left to the incidental consequences of even a substantial rise in farm prices. The sweep of events involved in the debt situation as well as in the more fundamental problem of overproduction is demanding direct action. To this end currency inflation and bankruptcy legislation have been somewhat vaguely proposed. Recognition of the possibility of correlating debt relief with the limitation of production has been given in a proposal which suggests that the scaling down of mortgage indebtedness as well as the control of short term farm credit, might be turned into an instrument for the regulation of output. The solution to one problem would have the consequence of providing also a solution to the other. ${ }^{82}$

In substance, the plan is based on the proposition that "Farm credit should be dependent on farm earnings. . . . Therefore, since farm earnings cannot exist in the face of overproduction, farm credit should not be advanced or continued unless production is limited." The plan contemplates that the substantial number of farmers whose mortgages ${ }^{83}$ are held by the banks of the two federal banking systems (the Federal Reserve and the Federal Land Bank systems) would be offered a reduction of principal and interest on

81. In addition, the President's program contemplates the immedinto ap. plication of the Smith cotton option contract plan. To any cotton producor agreeing to reduce his cotton acreage $30 \%$, will be given a non-transforablo option contract giving him the right to purchase within the year a portion of the cotton surplus to which the government now has legal title. The producor" will pay the average price paid by the government in acquiring the cotton and sell at the market price which is expected to rise simultaneously with tho curtailment in output. See U. S. Daily, March 6-18, 1933 at 17.

82. The authors of this plan are Thurman W. Arnold, Professor of Law, Yale University and Wesley A. Sturges, Lines Professor of Law, Yale University. See New York TIMEs, March 19, 1933, Section II, p. 1; NEW YorK Herald-Tribune March 19, 1933, Section IV, p. 7; New Haven Register, March 19, 1933, Section V, p. 4.

83. According to latest available figures the 9,463 billions of dollars investod in farm mortgages are distributed as follows: Federal land banks, 12.1\%; joint stock land banks, $7.0 \%$; commercial banks, $10.8 \%$; mortgage companies, $10.4 \%$; insurance companies, $22.9 \%$; retired farmers, $10.6 \%$; active farmers, $3.6 \%$; other individuals, $15.4 \%$; other agencies, $7.2 \%$. 
their mortgage obligations in return for adherence to a production schedule. ${ }^{84}$ In addition, the federal government with the same program in mind would offer to take over at a fair price the mortgages held by banks, insurance companies, and other private financial institutions whose capital is now frozen in farm mortgages, thereby incidentally aiding in their rehabilitation. ${ }^{85}$ Payment for these mortgages would be made in Federal Land Bank bonds bearing the current market rate of interest and guaranteed by the federal government. Furthermore, the extension of short-term credit by the federal government upon which millions of farmers are absolutely dependent, would be conditioned upon observance of the restriction of output.s6 There are, however, a certain number of farmers who are independently financing their own operations or resorting to state banks. These could not, supposedly, be reached by the use of a device which operates through the control of federal credit. ${ }^{87}$ Consequently, to adequately regulate production under this plan it is proposed to use the supplementary device of an excise tax on sales

84. Farm mortgages owned by member banks of the Federal Reserve System would be assigned to the Federal land banks of the districts where the farms are located.

85. If a farmer fails to comply with his agreement as to production, the mortgage shall be in full force and effect according to its original tenor.

86. At present there are six federal agencies engaged in extending credit to the farmer: member banks and the Federal Reserve banks of the Federal Reserve System, Federal land banks and national farm loan asseciations, joint stock land banks and Federal Intermediate Credit banks and national agricultural credit corporations. In respect to these banking institutions and ascociations whose powers are subject to direct regulation by Congress, the following legislation is proposed:

"1. Statutory provisions limiting their powers to loan directly or indirectly to any farmer for any agricultural purpose, or to discount or rediscount any such loans for any farmer or any other person, unless the paper shall bear the certificate of the Federal Land Bank of the district in which the farm is located that the production of such farm is under the restriction of production schedule hereinafter set out.

"2. This production schedule shall be a matter of contract between the farmer and the Federal Land Bank in question and shall be the same as that provided under this plan in case of farms subject to mortgage. In other words, the execution of this contract shall be a condition upon which the farmer may receive a certificate from the Federal Land Bank and the certificate chall be a prerequisite to his obtaining credit from any of the banling institutions enumerated above."

87. It may be suggested that the condition on discounting or rediscounting of farm paper could be largely extended so as to include the discounting or rediscounting of the paper of private financial and commercial houses which are engaged in financing the farmers. In this way almost a universal effect could be given to a federal credit policy. 
by farmers from which exemption will be granted upon proof of compliance with the praduction schedule. ${ }^{88}$

There would not seem to be any constitutional issue involved in requiring crop limitation as a condition of reducing principal and interest of mortgages or of obtaining further credit from the credit agencies of the federal government. ${ }^{80}$ However, an attempt to use the taxing power in the fashion suggested would raise directly the issue already referred to-the colorable use of an excise tax for purposes of regulation. To a large extent the courts have indicated that this matter is one of draftmanship of the statute. One conclusion as to the constitutionality of the proposed tax seems clear; if the revenue features of the tax are at all made manifest as means, for example, of defraying the expenses of carrying the act into effect and of compensating the government for losses arising aut of reap. praisals, the Court would not be driven to holding that the tax is not a tax. ${ }^{90}$ Furthermore, the Court will not be blind to the necessities

88. The proration schedule required to avoid imposition of this tax would be awarded on the same basis as in the case of a farmer applying for a certificate in order to obtain credit or to gain a reduction of mortgage charges.

89. Any creditor may always forbear to collect the full amount of the obligation due him. As a condition of this forbearance he may set any torms he wishes, even though they be capricious or arbitrary. Following that analogy the government as a creditor may impose a limitation of production as a condition of its forbearing to collect the full amount due it. Neithor is the farmer bound by any long term contract. In any given year ho may remove the limitation of production by paying the face of the mortgage. Also the government may direct the members of its banking system as to whom they will advance credit. This has been done throughout banking history. It is not different in principle from the raising and lowering of the rediscount rate by the Federal Reserve, or the determining by Congress of what paper may be eligible for rediscount.

90. The mere fact that a taxing statute is designed to regulate oven a business which might be held immune to direct legislative control is not sufficient to invalidate the tax. Thus a federal tax which was unquestionably intended to regulate ticket brokers, a business which the Supreme Court has decided cannot be directly supervised by the Legislature (Tyson \& Brother v. Banton, supra note 1), has been held in two cases to be constitutional. Alexander Theatre Ticket Office v. United States, 23 F. (2d) 44 (C. C. A. 2d, 1927); F. Couthoui v. United States, 54 F. (2d) 158 (Ct. Cl. 1931). The federal statute which was enacted in 1926 provided that whon theatro tickots are sold away from the ticket office the amount of any advance of not more than fifty cents over the established price should be taxed at the rate of five $\%$, but if the advance be more than fifty cents the total amount of the excess should be taxed at the rate of fifty \%. An amendment in 1928 substituted seventyfive for fifty cents. See Note (1932) 41 YALE L. J. 780. That the proposed tax would be held invalid must be predicated upon both of two propositions: (1) Farm production, insofar as it is subject to regulation at all, is exclusively a matter of state concern. (2) The tax must clearly appear on its face not 
of the situation which led to the enactment of the $\operatorname{tax}^{31}$ nor to the beneficial consequences intended to result from it, ${ }^{22}$ and it will likewise take cognizance of the admitted inability of the states effectively to deal with the situation. ${ }^{93}$ Finally much argument on this issue might be avoided by simply putting a tax upon the sale of all farm products and giving a bonus back to farmers who have reduced their output much as does the taxing device proposed by the allotment plan.

As a satisfactory long time device for the regulation of prices and production, no doubt this plan is open to criticism; it could be practicable at least in certain of its aspects only while the debtor and creditor relationship exists to an unusual degree. ${ }^{01}$ The patchwork character of its structure, in view of the fact that the control of production cannot be perfectly correlated with the relief of the debt situation, stands out in sharp relief. At the same time some sort of immediate constructive relief is necessary for the present protracted and disorganized liquidation. Aside from the wholesale use of currency inflation, ${ }^{95}$ any attempt adequately to solve the debt

to be a revenue measure. In the Child Labor Tax case, and Hill v. Wallace, both supra note 63 , the point emphasized by the court was that the act in question indicated decisively by reason of its elaborate and detailed specifications a purpose to regulate matters of state concern. In the sequel to Hill v. Wallace, the federal Grain Future Act was sustained under the broad concept of protecting the flow of commodities in interstate commerce; Board of Trade of Chicago v. Olsen, 262 U. S. 1 (1923).

On the other hand the mere annexation of police regulations to a tax law does not necessarily make the law an invalid exercise of the taxing power. The question is merely one of degree; the extent of such regulations in a particular instance may destroy the presumption of validity, but if they can be regarded as sustaining some relation to the collection of the tax, their presence will be tolerated. License Tax Cases, 5 Wall. 462 (U. S. 18C6); MIcCray v. United States, supra note 62; In re Kollock, supra note 62.

Further, it might be difficult to argue that the Police Power of the states is being interfered with since in any event the states cannot regulate the production or price of food or clothing. For the possibility that the Fifth Amendment may not limit the federal taxing power as the Fourteenth Amendment limits the taxing power of the states, see note 65, supra. There is no equal protection clause in the Fifth Amendment which could be used to restrict Congress in imposing an excise tax. See La Belle Iron Works v. United States, 256 U. S. 377 (1921).

91. Cf. Veazie Bank v. Fenno, supra note 62.

92. Cf. the Head Nioney Cases, 112 U. S. 580 (1884); and the Narcotic Drug Cases, United States v. Doremus, supra note 62; Alston v. United States, 274 U. S. 289 (1927); Nigro v. United States, 276 U. S. 332 (1928).

93. Cf. The Head Money Cases, supra note 92.

94. But see note 87 , supra.

95. It is urged, however, that a scheme involving not the expansion of money through the issue of new currency but the devaluation of the dollar by reducing the number of grains of gold (roughly equivalent to England's going 
problem independently of the necessity for production control would involve a profligate expenditure of public funds, and the collateral effect in further stimulating output might prove to be a very great disaster. ${ }^{96}$ The general project of the linking-up of credit with the regulation of production may find substantial justification both as emergency legislation and in the fact that to a considerable degree the two problems are directly related. ${ }^{97}$

\section{In Prospective}

It is not necessary to attempt to pronounce finally for or against any of these plans. Judged by absolute standards no one of them

- off the gold standard) would also increase the exports of the American farmor through under-selling to foreign countries since the dollar income would stlll conceal, at least temporarily, the reduced gold income. Nevertheless, in viow of the chaotic condition of the world market, even such level of competition as this could hardly expect to meet with success.

96. Most prominent of these bills designed as provisional measures for tho refinancing of the farmer is the Robinson Bill (SEN. REP. No. 5390). Outstanding in the bill is a provision for the creation of a one billion dollar government agency, the "Emergency Agricultural Refinance Corporntion" which would lend up to $\$ 10,000$ each to individual farmers on first or second mortgago securities provided the amount of the mortgage does not exceed $75 \%$ of the value of the property. In addition, the resources of the Federal Treasury would be aligned behind the Federal Land banks in order to allow thom to take over all sound first mortgages offered by creditors who need to liquidato. The joint stock land banks would be absorbed by the Federal Systom. For a complete compilation of legislation on the subject, see LAWS RELATING TO AGriculture (1931) compiled by Elmer A. Lewis, Superintendent Document Room, House of Representatives.

It has also been suggested that real estate mortgaging in the United Strtes is not sufficiently centralized or placed in the care of specialized financial institutions under close government supervision. While the problem of farm indebtedness is but a single phase of the severe consequences of deflation, the application of a careful policy of financing would help to lessen the plaguos of foreclosures which are continually visiting agriculture. Incompetency, particularly in the matter of land appraisals which have too often been based not on actual earning power but on expected real estate values and in the drafting of amortization provisions, has had far-reaching consequences in view of the orratic variations in farm income and the general depressed condition of agriculture since the war.

97. Among the objections which have been raised to this plan as specifically formulated, is the prospect of being compelled to wait several months while appraisals of mortgages are being agreed upon, before the plan would begin to operate effectively. This delay would eliminate the possibility of regulating production during the present crop year. In addition, the taxing feature of the plan presents administrative difficulties almost as great as those of the domestic allotment proposal. In an industry where few operators keep account booles, the administrative difficulties involved in the operation of a program which 
seems likely to introduce industrial Utopia. Still they all offer that chance for a beginning of the reorganization of farming which is better than supine resignation to the existing anarchy and confusion. ${ }^{98}$ No doubt the implacable catalogue of their sins can be told off tediously, and then ended with the final warning that it is not yet done, for the evils of devices so new and strange to the traditions of our country cannot all be forecast. And he who would scoff at the catalogue may point out that what we fear has a habit of never materializing, and if anything should prove to be disastrous, it will be, true to history, that which has never occurred to anyone.

Probably no easy solution exists which will put an end to existing evils without creating new ones or which will square perfectly with the law and the Constitution. No single stroke of the sword will cut the Gordian knot, no invocation of genii can do the act. Miost difficult of all, perhaps, is the requirement that the practical must wear the garb of what is politically feasible. Ideas must be sold in high pressure style in a world where voters can be made to strain at the gnat and swallow the camel. Violent prejudices exist against means which seem to represent class legislation or which seem to depart from the attitude of sturdy Americanism. Again, that sometimes capricious barrier of the Constitution must be faced. If something can be found which can be easily squared with it, so much the better. If not, forward looking judges must be depended upon to do a share.

Finally, the suggestions which these plans contain may prove to be most significant as a step in an experimental process. Clearly they all bear the mark of a Fabian retreat designed for the present and cautiously awaiting the future. To the impatient such measures might seem insufficient. However, to treat the tangible needs of

apparently would be ineffective without resort to a tax on sales, may readily be seen.

98. Unfortunately at the present time there seems to be developing among the farming interests a vague demand for agricultural relief which does not involve any limitation of production whatever. This has been reflected in the recent startling change of face on the part of the farmers themselves toward the Allotment Plan, which had almost their undivided support at the time when it was first proposed in Congress. No doubt over-production in a time when many are without the merest necessities of life has appeared paradoxical. Nor is "making more by working less" an idea that is in harmony with our preconceived notions of what is reasonable. Still further there is the example of many of the European countries who, to encourage farming in order to secure national sufficiency, have fixed prices without of course restricting production. Also the fact that the problem of mortgage debts has suddenly become so menacing has no doubt detracted attention from the issue of overproduction. 
the moment with the least possible friction with the established is, in itself, when the larger issues have not yet been resolved, an end that is well worth striving for. Indeed the greater difficulty of agriculture, which is an epitome of the adjustment we are now being called on to make in our industrial culture, has not even yet been stated. It is not the matter of the isolation of the farmer and the treating of his individual needs either temporary or long time, but of the association of farming with other industries, of gaining perspective rather than sharpness of focus. Technology in the long career ahead of it will require a vast elimination of land and people from agriculture. Expansion of demand will be principally in other directions than that of farm products. The general problem is so immense that it would be naive to look forward to a quick and decisive solution. Constructive planning for a long time to come will mean doing only things which solve issues as they arise and which may carry in their wake larger commitments. To catch the industrial culture as a going concern is beyond the capacity of a legal system. For the future all that can be accomplished is an orientation. Even if there is someone so far-seeing as to understand the answer to our economic enigmas, he will at the same time appreciate that law and politics must first be prepared for it. We quote again from the dissenting opinion of Mr. Justice Brandeis in the New State Ice Co. case. ${ }^{98}$

"We have been none too successful in the modest essays in economic control already entered upon. . . . Yet the advances in the exact sciences and the achievement in invention remind us that the seemingly impossiblo sometimes happens. . . . In large measure, those advances have been due to experimentation. . . To stay experimentation in things socinl and-economic is a grave responsibility. Denial of the right to experiment may be fraught with serious consequences to the nation. . . . If we would guide by the light of reason, we must let our minds be bold."

99. Supra note 1 , at 310 et seq. 